\title{
REVIEW
}

\section{Disease and immunity in Caribbean and Indo-Pacific zooxanthellate corals}

\author{
Kathryn P. Sutherland*, James W. Porter, Cecilia Torres \\ Institute of Ecology, University of Georgia, 1033 Green Street, Athens, Georgia 30602, USA
}

\begin{abstract}
Since the mid-1990s, coral diseases have increased in number, species affected, and geographic extent. To date, 18 coral diseases, affecting at least 150 scleractinian, gorgonian, and hydrozoan zooxanthellate species, have been described from the Caribbean and the Indo-Pacific. These diseases are associated with pathogens including bacteria, cyanobacteria, fungi, and protists and with abiotic stressors including elevated seawater temperature, sedimentation, eutrophication, and pollution. Etiologies of only 5 of the 18 coral diseases have been determined through fulfillment of Koch's postulates. Corals and other invertebrates utilize innate immune mechanisms including physiochemical barriers and cellular and humoral defenses against pathogens. Here we review the described coral diseases, known etiologies, and efforts to determine unknown etiologies. We define disease terms, discuss the limitations of Koch's postulates, describe alternative techniques for identifying disease-causing organisms, and review coral immunology.
\end{abstract}

KEY WORDS: Coral $\cdot$ Disease $\cdot$ Immunology $\cdot$ Invertebrate $\cdot$ Review

Resale or republication not permitted without written consent of the publisher

\section{INTRODUCTION}

Coral reefs are in severe decline. The most reliable estimates suggest that worldwide $27 \%$ have already been lost, with another $16 \%$ at serious risk of loss (Wilkinson 2002). Coral disease is thought to be a major cause for this decline (Dustan 1999, Porter et al. 2001). Epizootics have been reported for several coral species (Goreau et al. 1998, Richardson 1998, Richardson et al. 1998a,b, Harvell et al. 1999, 2001, Porter et al. 2001) and evidence is mounting of substantial declines in the biodiversity and abundance of reef-building corals worldwide (Hayes \& Goreau 1998, Porter \& Tougas 2001, Wilkinson 2002). Within the Caribbean, populations of elkhorn and staghorn corals, Acropora palmata and $A$. cervicornis, are being decimated by disease (Gladfelter 1982, Bythell \& Sheppard 1993, Aronson \& Precht 1997, 2001, Aronson et al. 1998, 2002, Greenstein et al. 1998, Miller et al. 2002, Patterson et al. 2002), with losses of A. palmata in the Florida
Keys National Marine Sanctuary (FKNMS) averaging $87 \%$ (Fig. 1) or greater (Miller et al. 2002, Patterson et al. 2002, Sutherland \& Ritchie in press). On most Caribbean reefs, loss of acroporids is accompanied by an apparent ecological phase shift from coral-dominated substrata to algal-dominated substrata (Hughes 1994). While severe population declines of Caribbean acroporid corals have led to the identification of $A$. palmata and A. cervicornis as candidates for inclusion on the Endangered Species List (Diaz-Soltero 1999), the impact of most diseases on coral populations is poorly understood.

Coral disease is becoming more widespread. The first coral disease was reported in 1965 and during the subsequent 3 decades, only 4 new diseases were reported (Table 1). Beginning in the mid-1990s, reports of novel coral diseases increased worldwide, and by 2002, 13 new diseases were described (Table 1, Fig. 2). In the FKNMS, number of locations exhibiting disease increased from 26 to 131 stations (404\% increase) and 


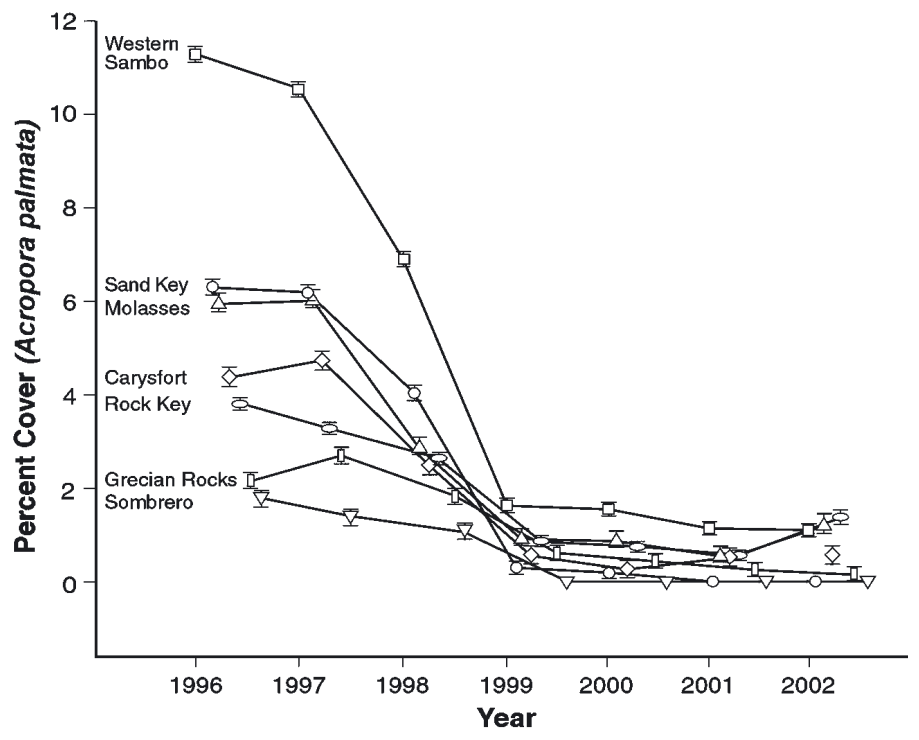

Fig. 1. Acropora palmata. Population decline (\% cover) by 2002 on each of 7 reefs surveyed in the Florida Keys National Marine Sanctuary. (ㅁ) Western Sambo Reef: $91 \%$; (O) Sand Key Reef: $100 \%$; $(\Delta)$ Molasses Reef: $79 \%$; $(\diamond)$ Carysfort Reef: $89 \%$; (ㅇ) Rock Key Reef: 58\%; (ㅁ) Grecian Rocks Reef: 95\%;

$(\nabla)$ Sombrero Reef: $100 \%$. Data in graph are mean \pm SD

number of coral species exhibiting disease increased from 11 to 36 (218\% increase) between 1996 and 2000 (Porter et al. 2001). These disease increases parallel a $37 \%$ decline in living coral over the same time period and at the same stations (Porter et al. 2002).

Biodiversity of corals is much greater in the IndoPacific than in the Caribbean. Age and geographic extent of the Indo-Pacific region contributes greatly to its richness (Veron 1995). Whereas only 53 coral spe-

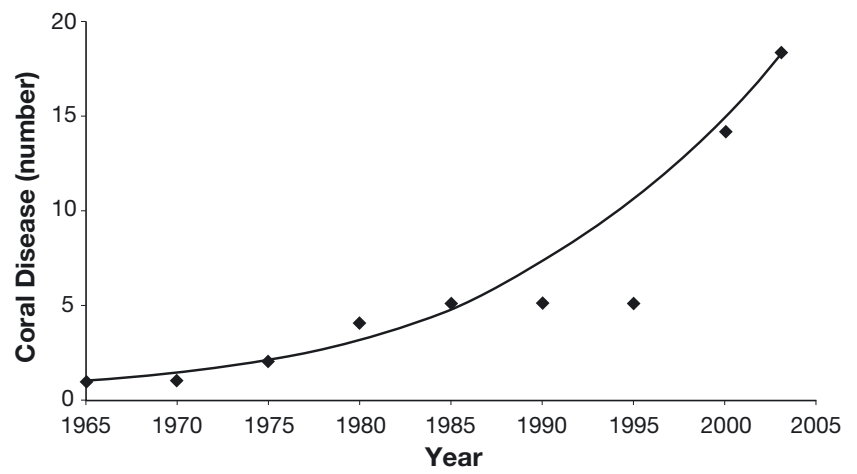

Fig. 2. Exponential increase in the number of described coral diseases since the first report of disease in 1965. Although increased awareness and increased observational time might explain some of this increase, many diseases, such as white plague, are so common and so distinctive that their first description may reasonably be assumed to mark their first appearance as a phenomenon influencing the population dynamics of corals

cies are found in Discovery Bay, Jamaica (Wells 1973), 362 coral species are found in Milne Bay, Papua New Guinea (Werner \& Allen 1998) and 350 coral species are found in the Great Barrier Reef, Australia (Veron 1985). Despite the greater species richness of the IndoPacific, the number of species affected by disease is proportionally much lower than in the Caribbean (Tables 2 \& 3).

Of the 18 coral diseases described to date, 4 are reported globally: black band (BBD), white plague-like diseases (WPL-L), shut-down reaction (SDR), and skeletal anomalies (SKA); 9 are found exclusively in the Caribbean: white band Types I (WBD I) and II (WBD II), white plague Types I (WPL I), II (WPL II), and

Table 1. First report of coral diseases in the Caribbean and the Indo-Pacific

\begin{tabular}{|lcll}
\hline Disease & Abbreviation & Year & Source \\
\hline Skeletal anomalies & SKA & 1965 & Squires (1965) \\
Black band & BBD & 1973 & Antonius (1973) \\
White plague Type I & WPL I & 1977 & Dustan (1977) \\
Shut-down reaction & SDR & 1977 & Antonius (1977) \\
White band Type I & WBD I & 1982 & Gladfelter (1982) \\
Aspergillosis & ASP & 1996 & Smith et al. (1996) \\
White pox & WPD & 1996 & Holden (1996) \\
Vibrio shiloi-induced bleaching & VSB & 1996 & Kushmaro et al. (1996) \\
Yellow blotch/band & YBL & 1997 & Santavy \& Peters (1997) \\
White plague Type II & WPL II & 1998 & Richardson et al. (1998a) \\
White band Type II & WBD II & 1998 & Ritchie \& Smith (1998) \\
Yellow band & YBD & 1998 & Korrûbel \& Riegl (1998) \\
Dark spots & DSD & 1998 & Goreau et al. (1998) \\
Skeleton eroding band & SEB & 2000 & Antonius \& Lipscomb (2000) \\
Fungal-protozoan syndrome & FPS & 2000 & Cerrano et al. (2000) \\
White plague Type III & WPL III & 2001 & Richardson et al. (2001) \\
Pink-line syndrome & PLS & 2001 & Ravindran et al. (2001) \\
Vibrio coralliilyticus-induced bleaching and disease & VCB & 2002 & Ben-Haim \& Rosenberg (2002) \\
\hline
\end{tabular}


Table 2. Caribbean scleractinian, hydrozoan, and gorgonian coral species affected by diseases (total number of reported species affected by each disease and total number of reported diseases affecting each species). For WPL and WBD: I = Type I, II = Type II, III = Type III, $\mathrm{X}$ = type not determined. See Table 1 for disease definitions

\begin{tabular}{|c|c|c|c|c|c|c|c|c|c|c|}
\hline & BBD & WPL & SDR & SKA & ASP & WBD & WPD & YBL & DSD & No. of diseases \\
\hline \multicolumn{11}{|l|}{ Scleractinians } \\
\hline Agaricia agaricites & & I, II & & & & & & $\mathrm{X}$ & $\mathrm{X}$ & 4 \\
\hline Agaricia fragilis & & $\mathrm{X}$ & & & & & & & & 1 \\
\hline Agaricia lamarcki & & II & & $\mathrm{X}$ & & & & & & 2 \\
\hline Agaricia tenuifolia & & $\mathrm{X}$ & & & & & & & & 1 \\
\hline Acropora cervicornis & & & $\mathrm{X}$ & $\mathrm{X}$ & & I,II & & & & 4 \\
\hline Acropora palmata & $\mathrm{X}$ & & $\mathrm{X}$ & $\mathrm{X}$ & & I & $\mathrm{X}$ & & & 5 \\
\hline Colpophyllia natans & $\mathrm{X}$ & I,II,III & & $\mathrm{X}$ & & & & $\mathrm{X}$ & $\mathrm{X}$ & 7 \\
\hline Cladocora arbuscula & & $\mathrm{X}$ & & & & & & & & 1 \\
\hline Dendrogyra cylindrus & & II & & & & & & & & 1 \\
\hline Dichocoenia stokesi & $\mathrm{X}$ & II & $\mathrm{X}$ & $\mathrm{X}$ & & & & & & 4 \\
\hline Diploria clivosa & $\mathrm{X}$ & $\mathrm{X}$ & & & & & & & & 2 \\
\hline Diploria labyrinthiformis & $\mathrm{X}$ & I,II & & $\mathrm{X}$ & & & & $\mathrm{X}$ & $\mathrm{X}$ & 6 \\
\hline Diploria strigosa & $\mathrm{X}$ & II & & $\mathrm{X}$ & & & & $\mathrm{X}$ & & 4 \\
\hline Eusmilia fastigiata & & II & & & & & & & & 1 \\
\hline Favia fragum & $\mathrm{X}$ & $\mathrm{X}$ & & $\mathrm{X}$ & & & & $\mathrm{X}$ & & 4 \\
\hline Isophyllastrea rigida & & I & & & & & & & $\mathrm{X}$ & 2 \\
\hline Isophyllia sinuosa & & $\mathrm{X}$ & & & & & & & & 1 \\
\hline Leptoseris cucullata & & $\mathrm{X}$ & & & & & & & & 1 \\
\hline Madracis decactis & $\mathrm{X}$ & II & & & & & & & & 2 \\
\hline Madracis formosa & & & & $\mathrm{X}$ & & & & & & 1 \\
\hline Madracis mirabilis & $\mathrm{X}$ & II & & & & & & & & 2 \\
\hline Manicina areolata & & II & & $\mathrm{X}$ & & & & & & 2 \\
\hline Meandrina meandrites & $\mathrm{X}$ & II & & & & & & & $\mathrm{X}$ & 3 \\
\hline Montastraea annularis & $\mathrm{X}$ & I,II,III & $\mathrm{X}$ & $\mathrm{X}$ & & & & $\mathrm{X}$ & $\mathrm{X}$ & 8 \\
\hline Montastraea cavernosa & $\mathrm{X}$ & I,II & & $\mathrm{X}$ & & & & & $\mathrm{X}$ & 5 \\
\hline Montastraea faveolata & $\mathrm{X}$ & I & & & & & & $\mathrm{X}$ & $\mathrm{X}$ & 4 \\
\hline Montastraea franksi & $\mathrm{X}$ & $\mathrm{X}$ & & & & & & $\mathrm{X}$ & $\mathrm{X}$ & 4 \\
\hline Mussa angulosa & & I & & & & & & & & 1 \\
\hline Mycetophyllia aliciae & & $\mathrm{X}$ & & & & & & & & 1 \\
\hline Mycetophyllia danaana & & $\mathrm{X}$ & & & & & & & & 1 \\
\hline Mycetophyllia ferox & & I & & & & & & & & 1 \\
\hline Mycetophyllia lamarkiana & & I & & & & & & & & 1 \\
\hline Oculina diffusa & & $\mathrm{X}$ & & & & & & & & 1 \\
\hline Porites astreoides & $\mathrm{X}$ & I & & $\mathrm{X}$ & & & & $\mathrm{X}$ & & 4 \\
\hline Porites porites & & $\mathrm{X}$ & & $\mathrm{X}$ & & & & & & 2 \\
\hline Scolymia cubensis & & $\mathrm{X}$ & & & & & & & & 1 \\
\hline Siderastrea radians & $\mathrm{X}$ & $\mathrm{X}$ & & $\mathrm{X}$ & & & & & & 3 \\
\hline Siderastrea siderea & $\mathrm{X}$ & $\mathrm{I}, \mathrm{II}$ & $\mathrm{X}$ & $\mathrm{X}$ & & & & & $\mathrm{X}$ & 6 \\
\hline Solenastrea bournoni & & II & & & & & & & & 1 \\
\hline Solenastrea hyades & $\mathrm{X}$ & $\mathrm{X}$ & $\mathrm{X}$ & & & & & & & 3 \\
\hline Stephanocoenia michelinii & $\mathrm{X}$ & I,II & & & & & & & $\mathrm{X}$ & 4 \\
\hline Total & 19 & 38 & 6 & 16 & $\mathbf{0}$ & 2 & 1 & 9 & 11 & \\
\hline \multicolumn{11}{|l|}{ Hydrozoans } \\
\hline Millepora alcicornis & & II & & $\mathrm{X}$ & & & & & & 2 \\
\hline Millepora complanata & & $\mathrm{X}$ & & & & & & & & 1 \\
\hline Total & 0 & 2 & $\mathbf{0}$ & 1 & $\mathbf{0}$ & $\mathbf{0}$ & $\mathbf{0}$ & $\mathbf{0}$ & $\mathbf{0}$ & \\
\hline \multicolumn{11}{|l|}{ Gorgonians } \\
\hline Gorgonia flabellum & $\mathrm{X}$ & & & & $\mathrm{X}$ & & & & & 2 \\
\hline Gorgonia ventalina & $\mathrm{X}$ & & & $\mathrm{X}$ & $\mathrm{X}$ & & & & & 3 \\
\hline Gorgonia sp. & & & & & $\mathrm{X}$ & & & & & 1 \\
\hline Plexaura flexuosa & $\mathrm{X}$ & & & & & & & & & 1 \\
\hline Plexaura homomalla & $\mathrm{X}$ & & & & & & & & & 1 \\
\hline Plexaura sp. & & & & & $\mathrm{X}$ & & & & & 1 \\
\hline Plexaurella sp. & & & & & $\mathrm{X}$ & & & & & 1 \\
\hline Plexaurella homomalla & & & & $\mathrm{X}$ & & & & & & 1 \\
\hline Plexaurella flexuosa & & & & $\mathrm{X}$ & & & & & & 1 \\
\hline Pseudoplexaura spp. & & & & $\mathrm{X}$ & $\mathrm{X}$ & & & & & 2 \\
\hline Pseudoplexaura porosa & & & & $\mathrm{X}$ & & & & & & 1 \\
\hline Pseudopterogorgia acerosa & $\mathrm{X}$ & & & & & & & & & 1 \\
\hline Pseudopterogorgia americana & $\mathrm{X}$ & & & & $\mathrm{X}$ & & & & & 2 \\
\hline Total & 6 & $\mathbf{0}$ & $\mathbf{0}$ & 5 & 7 & $\mathbf{0}$ & $\mathbf{0}$ & $\mathbf{0}$ & $\mathbf{0}$ & \\
\hline Total no. of species & 25 & 40 & 6 & 22 & 7 & 2 & 1 & 9 & 11 & \\
\hline
\end{tabular}


Table 3. Indo-Pacific scleractinian and gorgonian coral species affected by diseases (total number of reported species affected by each disease and total number of reported diseases affecting each species). See Table 1 for disease definitions

\begin{tabular}{|c|c|c|c|c|c|c|c|c|c|c|}
\hline & BBD & WPL-L & SKA & VSB & VCB & SEB & YBD & PLS & FPS & No. of diseases \\
\hline \multicolumn{11}{|l|}{ Scleractinians } \\
\hline Acropora aspera & & & & & & $\mathrm{X}$ & & & & 1 \\
\hline Acropora capillaris & & $\mathrm{X}$ & & & & & & & & 1 \\
\hline Acropora clathrata & $\mathrm{X}$ & $\mathrm{X}$ & $\mathrm{X}$ & & & $\mathrm{X}$ & $\mathrm{X}$ & & & 5 \\
\hline Acropora cytherea & $\mathrm{X}$ & & & & & & & & & 1 \\
\hline Acropora downingi & $\mathrm{X}$ & $\mathrm{X}$ & & & & $\mathrm{X}$ & $\mathrm{X}$ & & & 4 \\
\hline Acropora florida & $\mathrm{X}$ & $\mathrm{X}$ & & & & $\mathrm{X}$ & $\mathrm{X}$ & & & 4 \\
\hline Acropora formosa & $\mathrm{X}$ & & $\mathrm{X}$ & & & $\mathrm{X}$ & & & & 3 \\
\hline Acropora gemmifera & $\mathrm{X}$ & & & & & & & & & 1 \\
\hline Acropora hemprichi & & $\mathrm{X}$ & & & & & & & & 1 \\
\hline Acropora humilis & $\mathrm{X}$ & $\mathrm{X}$ & & & & $\mathrm{X}$ & & & & 3 \\
\hline Acropora hyacinthus & $\mathrm{X}$ & $\mathrm{X}$ & & & & $\mathrm{X}$ & & & & 3 \\
\hline Acropora intermedia & $\mathrm{X}$ & & & & & & & & & 1 \\
\hline Acropora microclados & $\mathrm{X}$ & & & & & & & & & 1 \\
\hline Acropora microphthalma & $\mathrm{X}$ & & & & & & & & & 1 \\
\hline Acropora millepora & $\mathrm{X}$ & & & & & & & & & 1 \\
\hline Acropora monticulosa & $\mathrm{X}$ & & & & & & & & & 1 \\
\hline Acropora nobilis & $\mathrm{X}$ & $\mathrm{X}$ & $\mathrm{X}$ & & & $\mathrm{X}$ & & & & 4 \\
\hline Acropora palifera & $\mathrm{X}$ & $\mathrm{X}$ & & & & & & & & 2 \\
\hline Acropora pharaonis & $\mathrm{X}$ & $\mathrm{X}$ & & & & & $\mathrm{X}$ & & & 3 \\
\hline Acropora robusta & $\mathrm{X}$ & & & & & & & & & 1 \\
\hline Acropora sarmentosa & $\mathrm{X}$ & & & & & & & & & 1 \\
\hline Acropora squarrosa & & $\mathrm{X}$ & & & & & & & & 1 \\
\hline Acropora tenuis & & & & & & $\mathrm{X}$ & $\mathrm{X}$ & & & 2 \\
\hline Acropora valenciennesi & & & $\mathrm{X}$ & & & & & & & 1 \\
\hline Acropora valida & & $\mathrm{X}$ & $\mathrm{X}$ & & & $\mathrm{X}$ & $\mathrm{X}$ & & & 4 \\
\hline Acropora variabilis & & $\mathrm{X}$ & & & & & & & & 1 \\
\hline Acropora virgata & & & $\mathrm{X}$ & & & & & & & 1 \\
\hline Alveopora gigas & $\mathrm{X}$ & & & & & & & & & 1 \\
\hline Astreopora myriophthalma & $\mathrm{X}$ & & & & & & & & & 1 \\
\hline Cladocora caespitosa & & & & & & & & & $\mathrm{X}$ & 1 \\
\hline Coscinarea monile & & $\mathrm{X}$ & & & & & & & & 1 \\
\hline Cyphastrea chalcidicum & & & & & & $\mathrm{X}$ & & & & 1 \\
\hline Cyphastrea microphthalma & & & & & & & $\mathrm{X}$ & & & 1 \\
\hline Cyphastrea serailia & & & & & & $\mathrm{X}$ & & & & 1 \\
\hline Echinophyllia aspera & $\mathrm{X}$ & & & & & & & & & 1 \\
\hline Echinopora gemmacea & & $\mathrm{X}$ & & & & & & & & 1 \\
\hline Enallopsammia rostrata & & & $\mathrm{X}$ & & & & & & & 1 \\
\hline Favia favus & $\mathrm{X}$ & $\mathrm{X}$ & & & & & & & & 2 \\
\hline Favia matthaii & $\mathrm{X}$ & & & & & & & & & 1 \\
\hline Favia pallida & $\mathrm{X}$ & $\mathrm{X}$ & & & & & & & & 2 \\
\hline Favia stelligera & $\mathrm{X}$ & $\mathrm{X}$ & & & & $\mathrm{X}$ & & & & 3 \\
\hline Favia valenciennesii & & & $\mathrm{X}$ & & & & & & & 1 \\
\hline Favites abdita & & & & & & $\mathrm{X}$ & & & & 1 \\
\hline Favites pentagona & $\mathrm{X}$ & $\mathrm{X}$ & & & & & & & & 2 \\
\hline Goniastrea pectinata & $\mathrm{X}$ & $\mathrm{X}$ & & & & & & & & 2 \\
\hline Goniastrea retiformis & $\mathrm{X}$ & $\mathrm{X}$ & & & & $\mathrm{X}$ & & & & 3 \\
\hline Goniopora columna & $\mathrm{X}$ & & & & & & & & & 1 \\
\hline Goniopora somaliensis & $\mathrm{X}$ & & & & & & & & & 1 \\
\hline Goniopora sp. & $\mathrm{X}$ & & & & & & & & & 1 \\
\hline Hydnophora microconos & $\mathrm{X}$ & $\mathrm{X}$ & & & & $\mathrm{X}$ & & & & 3 \\
\hline Leptastrea purpurea & & & & & & $\mathrm{X}$ & & & & 1 \\
\hline Leptoria phrygia & $\mathrm{X}$ & $\mathrm{X}$ & & & & & & & & 2 \\
\hline Leptoseris explanata & & & & & & $\mathrm{X}$ & & & & 1 \\
\hline Leptoseris glabra & & $\mathrm{X}$ & & & & & & & & 1 \\
\hline Leptoseris mycetoseroides & & $\mathrm{X}$ & & & & & & & & 1 \\
\hline Lobophyllia corymbosa & & $\mathrm{X}$ & & & & & & & & 1 \\
\hline Madrepora kauaiensis & & & $\mathrm{X}$ & & & & & & & 1 \\
\hline Madrepora oculata & & & $\mathrm{X}$ & & & & & & & 1 \\
\hline Montipora aequituberculata & $\mathrm{X}$ & $\mathrm{X}$ & & & & & & & & 2 \\
\hline Montipora ehrenbergi & & $\mathrm{X}$ & & & & & & & & 1 \\
\hline Montipora florida & $\mathrm{X}$ & & & & & & & & & 1 \\
\hline Montipora foliosa & & & $\mathrm{X}$ & & & & & & & 1 \\
\hline Montipora informis & & & $\mathrm{X}$ & & & & & & & 1 \\
\hline Montipora monasteriata & & & & & & $\mathrm{X}$ & & & & 1 \\
\hline
\end{tabular}


Table 3 (continued)

\begin{tabular}{|c|c|c|c|c|c|c|c|c|c|c|}
\hline & BBD & WPL-L & SKA & VSB & $\mathrm{VCB}$ & SEB & YBD & PLS & FPS & No. of diseases \\
\hline \multicolumn{11}{|l|}{ Scleractinians (continued) } \\
\hline Montipora patula & & & $\mathrm{x}$ & & & & & & & 1 \\
\hline Montipora verrucosa & $\mathrm{X}$ & & $\mathrm{X}$ & & & & & & & 2 \\
\hline Montipora sp. & $\mathrm{X}$ & & $\mathrm{x}$ & & & & & & & 2 \\
\hline Mycedium elephantotus & & $\mathrm{X}$ & & & & & & & & 1 \\
\hline Oculina patagonica & & & & $\mathrm{x}$ & & & & & & 1 \\
\hline Pavona gigantea & & & $\mathrm{x}$ & & & & & & & 1 \\
\hline Pachyseris gemmae & $\mathrm{X}$ & & & & & & & & & 1 \\
\hline Pachyseris rugosa & & & & & & $\mathrm{X}$ & & & & 1 \\
\hline Platygyra daedalea & & $\mathrm{X}$ & & & & & & & & 1 \\
\hline Platygyra lamellina & $\mathrm{X}$ & $\mathrm{x}$ & & & & & & & & 2 \\
\hline Platygyra pini & & & $\mathrm{x}$ & & & & & & & 1 \\
\hline Platygyra sinensis & & & $\mathrm{x}$ & & & & & & & 1 \\
\hline Pocillopora damicornis & $\mathrm{X}$ & $\mathrm{X}$ & & & $\mathrm{X}$ & $\mathrm{X}$ & & & & 4 \\
\hline Pocillopora eydouxi & & & & & & $\mathrm{X}$ & & & & 1 \\
\hline Pocillopora verrucosa & $\mathrm{X}$ & $\mathrm{X}$ & & & & $\mathrm{X}$ & & & & 3 \\
\hline Pocillopora meandrina & & & $\mathrm{x}$ & & & & & & & 1 \\
\hline Podabacia crustacea & & $\mathrm{x}$ & & & & & & & & 1 \\
\hline Porites sp. & $\mathrm{X}$ & & & & & & & & & 1 \\
\hline Porites compressa & & & $\mathrm{x}$ & & & & & $\mathrm{X}$ & & 2 \\
\hline Porites harrisoni & & & & & & & $\mathrm{x}$ & & & 1 \\
\hline Porites lichen & & & & & & & $\mathrm{x}$ & & & 1 \\
\hline Porites lobata & & & $\mathrm{x}$ & & & & & & & 1 \\
\hline Porites lutea & $\mathrm{X}$ & $\mathrm{X}$ & $\mathrm{x}$ & & & & $\mathrm{x}$ & $\mathrm{x}$ & & 5 \\
\hline Porites nodifera & & & & & & & $\mathrm{x}$ & & & 1 \\
\hline Pratzia mirabilis & & & $\mathrm{X}$ & & & & & & & 1 \\
\hline Stylophora erthyaea & & & $\mathrm{x}$ & & & & & & & 1 \\
\hline Stylophora pistillata & $\mathrm{X}$ & $\mathrm{x}$ & & & & $\mathrm{X}$ & & & & 3 \\
\hline Symphyllia radians & & $\mathrm{x}$ & & & & & & & & 1 \\
\hline Turbinaria mesenterina & $\mathrm{x}$ & & & & & & & & & 1 \\
\hline Turbinaria reniformis & & $\mathrm{X}$ & & & & & $\mathrm{X}$ & & & 2 \\
\hline Verrillofungia concinna & & & $\mathrm{X}$ & & & & & & & 1 \\
\hline Total & 45 & 38 & 24 & 1 & 1 & 24 & 12 & 2 & 1 & \\
\hline \multicolumn{11}{|l|}{ Gorgonians } \\
\hline Corallium rubrum & & & & & & & & & $\mathrm{X}$ & 1 \\
\hline Eunicella cavolini & & & & & & & & & $\mathrm{x}$ & 1 \\
\hline Eunicella singularis & & & & & & & & & $\mathrm{x}$ & 1 \\
\hline Eunicella verrucosa & & & & & & & & & $\mathrm{x}$ & 1 \\
\hline Leptogorgia sarmentosa & & & & & & & & & $\mathrm{X}$ & 1 \\
\hline Paramuricea clavata & & & & & & & & & $\mathrm{x}$ & 1 \\
\hline Total & $\mathbf{0}$ & $\mathbf{0}$ & 0 & $\mathbf{0}$ & 0 & 0 & $\mathbf{0}$ & 0 & 6 & \\
\hline Total no. of species & 45 & 38 & 24 & 1 & 1 & 24 & 12 & 2 & 7 & \\
\hline
\end{tabular}

III (WPL III), aspergillosis (ASP), white pox (WPD), yellow blotch/band (YBL), dark spots (DSD); and 6 are apparently endemic to the Indo-Pacific: yellow band (YBD), skeleton eroding band (SEB), pink-line syndrome (PLS), fungal-protozoan syndrome (FPS), Vibrio shiloi-induced bleaching (VSB), V. coralliilyticusinduced bleaching and disease (VCB). WPL-L in the Indo-Pacific may or may not be etiologically related to the 3 Caribbean WPL diseases. Etiologies and mechanisms of tissue death of the majority of coral diseases are not understood (Richardson 1998).

Tissue loss or damage from predation is often impossible to distinguish from tissue loss or damage from disease. To the human eye, there are not many ways in which coral tissue can exhibit signs of stress. Corallivores, including fishes, gastropods, and other invertebrates, produce predation scars that are easily con- fused with disease signs. The best method to distinguish between predation and disease is to observe the progress of the condition in the absence of predation, via predator exclusion in situ or predator removal under laboratory conditions. A number of coral abnormalities, some of which have been described in the literature as coral diseases, are likely associated with predation rather than disease. For example, predation by the stoplight parrotfish Sparisoma viride, was initially described as a coral disease termed rapid wasting syndrome (Cervino et al. 1997). Subsequent investigations identified fish predation as the primary cause of skeletal loss (Bruckner \& Bruckner 2002), but the possible role of fungi in the dissolution of the skeleton (Cervino et al. 1997, Hayes \& Goreau 1998) has not been fully vetted. Further, in some cases, disease signs attributed to coral disease (e.g. WPL, WBD, and WPD) 
may be difficult to distinguish from predation scars produced by corallivores including the gastropod Coralliophila abbreviata, and the fire worm Hermodice caruculata (Patterson et al. 2002).

In order to facilitate an understanding of disease processes and causation in corals, it is necessary to understand general disease terminology and coral immunity. The objectives of this paper are to: (1) define disease terminology and relate these terms to coral disease, (2) discuss the process of proving disease causation, (3) review described coral diseases, known etiologies, and efforts to determine unknown etiologies, (4) illustrate each of the known Caribbean coral diseases, and (5) review coral immunology.

\section{DISEASE TERMINOLOGY}

A disease is any impairment (interruption, cessation, proliferation, or other disorder) of vital body functions, systems, or organs (Stedman 2000). The term syndrome is synonymous with disease (Stedman 2000). Etiology is analysis of causes, development, and consequences of a disease (Kinne 1980). Disease causation (i.e. etiology) may be attributed to pathogens, environmental stressors, or a combination of biotic and abiotic factors. Biotic diseases are caused by pathogenic microorganisms such as viruses, bacteria, fungi, and protists and are often species-specific (Peters 1997) and infectious (Kinne 1980). Abiotic diseases result from both natural and human-induced environmental stressors including change in ambient conditions or exposure to pollutants. Biotic and abiotic diseases are often closely related. Biotic diseases may be associated with environmental stressors that: (1) hinder the resistence of host organisms, (2) promote growth and virulence of pathogens, (3) trigger the pathogenic process, or (4) increase the rate of disease transmission (Kushmaro et al. 1996, 1998, Peters 1997, Toren et al. 1998, Ben-Haim et al. 1999, 2003b, Alker et al. 2001, Banin et al. 2001a, Israely et al. 2001, Ben-Haim \& Rosenberg 2002, Kuta \& Richardson 2002, Richardson \& Kuta 2003). Abiotic diseases may be exacerbated by secondary opportunistic infections (Peters 1997).

Etiologies of 11 diseases affecting scleractinian and gorgonian corals may involve pathogens including bacteria, cyanobacteria, fungi, and protists (Table 4). Ten diseases are associated with abiotic stressors in-

Table 4. Caribbean and Indo-Pacific coral diseases associated with biota. Koch's postulates have been fullfilled for only 5 diseases. See Table 1 for disease definitions

\begin{tabular}{|c|c|c|c|}
\hline Disease & Biota & Koch's postulates & Source \\
\hline BBD & $\begin{array}{l}\text { Phormidium corallyticum (cyanobacterium) } \\
\text { Trichodesmium spp. (cyanobacteria) } \\
\text { Cyanobacterium } \\
\text { Desulvovibrio spp. (bacteria) } \\
\text { Beggiatoa spp. (bacteria) } \\
\text { Heterotrophic bacteria } \\
\text { Marine fungus }\end{array}$ & No & $\begin{array}{l}\text { Rützler \& Santavy (1983) } \\
\text { Frias-Lopez et al. (2002, 2003) } \\
\text { Cooney et al. (2002), Frias-Lopez et al. (2003) } \\
\text { Garrett \& Ducklow (1975), Schnell et al. (1996), } \\
\text { Cooney et al. (2002) } \\
\text { Ducklow \& Mitchell (1979b) } \\
\text { Garrett \& Ducklow (1975), Cooney et al. (2002), } \\
\text { Frias-Lopez et al. (2002) } \\
\text { Ramos-Flores (1983) }\end{array}$ \\
\hline WPL II & Aurantimonas coralicida (bacterium) & Yes & Richardson et al. (1998a,b), Denner et al. (2002) \\
\hline SKA & $\begin{array}{l}\text { Petrarca madreporae (crustacean) } \\
\text { Podocotyloides stenometra (trematode) } \\
\text { Endolithic fungi } \\
\text { Aspergillus sydowii (fungus) } \\
\text { Order Siphonales (algae) } \\
\text { Entocladia endozoica (algae) }\end{array}$ & No & $\begin{array}{l}\text { Grygier \& Cairns (1996) } \\
\text { Cheng \& Wong (1974), Aeby (1998) } \\
\text { Le Champion-Alsumard et al. (1995), Ravindran } \\
\text { et al. (2001) } \\
\text { Smith et al. (1998), Dube et al. (2002) } \\
\text { Morse et al. (1977, 1981), } \\
\text { Goldberg et al. (1984) }\end{array}$ \\
\hline WBD II & Vibrio charcharia (bacterium) & No & Ritchie \& Smith (1995a) \\
\hline WPD & Serratia marcescens (bacterium) & Yes & Patterson et al. (2002) \\
\hline ASP & Aspergillus sydowii (fungus) & Yes & Smith et al. (1996), Geiser et al. (1998) \\
\hline VSB & Vibrio shiloi (bacterium) & Yes & $\begin{array}{l}\text { Kushmaro et al. }(1996,1997,1998,2001) \text {, } \\
\text { Rosenberg et al. (1998) }\end{array}$ \\
\hline VCB & Vibrio coralliilyticus (bacterium) & Yes & $\begin{array}{l}\text { Ben-Haim \& Rosenberg }(2002) \text {, } \\
\text { Ben-Haim et al. }(2003 \mathrm{a}, \mathrm{b})\end{array}$ \\
\hline SEB & Halofolliculina corallasia (protozoan) & No & Antonius \& Lipscomb (2000) \\
\hline PLS & Phormidium valderianum (cyanobacterium) & No & Ravindran \& Raghukumar (2002) \\
\hline FPS & $\begin{array}{l}\text { Trichoderma spp. (fungi) } \\
\text { Clodosporium spp. (fungi) } \\
\text { Penicillum spp. (fungi) } \\
\text { Humicola spp. (fungi) } \\
\text { Ciliate (protozoan) }\end{array}$ & No & $\begin{array}{l}\text { Cerrano et al. }(2000) \\
\text { Cerrano et al. }(2000) \\
\text { Cerrano et al. }(2000) \\
\text { Cerrano et al. }(2000) \\
\text { Cerrano et al. }(2000)\end{array}$ \\
\hline
\end{tabular}


Table 5. Caribbean and Indo-Pacific coral diseases associated with abiotic stressors. See Table 1 for disease definitions

\begin{tabular}{|lll|}
\hline Disease & Abiotic stressors & Source \\
\hline BBD & Elevated temperature & Antonius (1981, 1985a), Rützler et al. (1983), Edmunds (1991), Carlton \& Richardson \\
& Eutrophication & Antonius (1981, 1985a), Kuta \& Richardson (2002) \\
& Sedimentation & Littler \& Littler (1996), Bruckner et al. (1997), Frias-Lopez et al. (2002) \\
& Pollution & Antonius (1985a), Al-Moghrabi (2001) \\
& Fecal contamination & Frias-Lopez et al. (2002) \\
SDR & Elevated temperature & Antonius (1977) \\
& Sedimentation & Antonius (1977) \\
SKA & Solar UV radiation & Peters et al. (1986), Coles \& Seapy (1998) \\
ASP & Elevated temperature & Alker et al. (2001) \\
& Sedimentation & Smith et al. (1996), Shinn et al. (2000), Weir et al. (in press) \\
WPD & Poor water quality & Kim \& Harvell (2002) \\
& Elevated temperature & Patterson et al. (2002) \\
& Fecal contamination & Patterson et al. (2002) \\
DSD & Precipitation & Sutherland \& Ritchie (in press) \\
VSB & Elevated temperature & Gil-Agudelo \& Garzón-Ferreira (2001) \\
& Elevated temperature & Kushmaro et al. (1998), Toren et al. (1998), Ben-Haim et al. (1999), Banin et al. (2001a), \\
VCB & Elevated temperature & Israely et al. (2001) \\
YBD & Elevated temperature & Riegl (2002) \\
FPS & Elevated temperature & Cerrano et al. (2000) \\
\hline
\end{tabular}

cluding temperature extremes, sedimentation, eutrophication, and pollution (Table 5). VSB and VCB are examples of conditions with a combination of abiotic and biotic factors contributing to disease causation. Infections with Vibrio shiloi and V. coralliilyticus do not occur in the absence of elevated seawater temperature (Kushmaro et al. 1998, Toren et al. 1998, Ben-Haim et al. 1999, 2003b, Banin et al. 2001a, Israely et al. 2001, Ben-Haim \& Rosenberg 2002).

An infectious disease is one in which the causal agent can be transmitted from one host individual to another (Kinne 1980, Peters 1997, Stedman 2000). Disease transmission can be either horizontal or vertical. Horizontal disease transmission is the transmission of infectious agents from an infected individual to a susceptible contemporary (Stedman 2000). Vertical disease transmission is the transmission of infectious agents from an infected individual to its offspring (Stedman 2000). There is no evidence to date to associate coral diseases with vertical transmisssion.

Horizontal disease transmisssion can be either direct or indirect. Direct transmission requires contact between infected and uninfected individuals. In terrestrial environments direct transmission may occur via physical contact or respiratory aerosols. For sessile marine invertebrates, including scleractinian, gorgonian, and hydrozoan corals, direct physical contact only occurs between close neighbors. Inanimate or living agents are required for indirect transmission. Vectors are living agents that transmit pathogens (Stedman
2000) and in the coral reef environment may include predatory and/or herbivorous arthropods, annelids, mollusks, echinoderms, and fishes. The only known vector for a coral disease is the marine fireworm Hermodice carunculata, which transmits Vibrio shiloi, the causal agent of VSB, to its coral host (Sussman et al. 2003). Contaminated water is an inanimate mode of indirect disease transmission and waterborne pathogens are significant in marine ecosystems.

Infection begins with invasion and multiplication of microorganisms in host tissues and may result in cellular injury. Infection does not always impair the host and therefore is not synonymous with disease (Stedman 2000). For instance, intimate associations between 2 different genetic entities such as host and microorganism are known as symbioses (living together) and range from parasitism to commensalism. A parasite is an organism that grows in or on a host and causes harm to the host (Kinne 1980). A pathogen is a parasite that causes damage to a host, resulting in disease and possibly mortality (Peters 1997). All biotic diseases are symbiotic relationships between a host and a pathogen (Kinne 1980).

Pathogenesis is the process by which infection leads to disease (Stedman 2000). Virulence is the capacity of a pathogen to cause disease (i.e. degree of pathogenicity, Stedman 2000) and is influenced by the interaction between the host, the pathogen, and the environment (Peters 1997). Virulence factors affecting the severity of coral diseases are poorly understood. However, 
elevated seawater temperature increases the virulence of Vibrio shiloi (Kushmaro et al. 1998, Banin et al. 2001a), V. coralliilyticus (Ben-Haim \& Rosenberg 2002), Aspergillus sydowii (Alker et al. 2001) and the BBD microbial consortium (Table 5, Kuta \& Richardson 2002, Richardson \& Kuta 2003). Virulence factors affecting VSB include both heat-stable and heatsensitive toxins that target the zooxanthellae and play a role in pathogenesis (Rosenberg et al. 1998, BenHaim et al. 1999).

Susceptibility is the capacity of a host to become infected (Kinne 1980). Host susceptibility may vary between species and within species or individuals and according to environmental stressors, nutrition, genetics, age, and developmental stage (Kinne 1980, Peters 1997). Resistance is a measure of susceptibility of a host to an invading organism, i.e. the ability of an organism to maintain its immunity to or to counteract a disease agent (Kinne 1980, Stedman 2000). Resistance and susceptibility of corals can vary with health status (Kim et al. 2000a) and size class (Dube et al. 2002, Kim \& Harvell 2002, Nugues 2002) of the host. Corals are likely more susceptible to (i.e. less resistant to) disease when they are exposed to environmental stressors including sub- and supra-optimal temperature and salinity levels, or poor water quality associated with anthropogenic disturbances including eutrophication, sedimentation, and pollution (Mitchell \& Chet 1975, Ducklow \& Mitchell 1979a, Johnston et al. 1981, Glynn et al. 1984, Peters 1984, Hodgson 1990, Richmond 1993, Frias-Lopez et al. 2002). Physical stressors such as temperature-induced coral bleaching may also promote disease susceptibility (Kushmaro et al. 1997, Harvell et al. 1999).

Epizootiology is the study of the occurrence, distribution, and control of a disease in an animal population (Stedman 2000). The term is synonymous with epidemiology in human populations (Stedman 2000). Incidence is the number of individuals with new cases of a disease during a specified time period in a specified population (Stedman 2000). Prevalence is the number of cases of a disease in a population at a specific time (Stedman 2000). An epizootic is analogous to an epidemic in human populations and is defined as: (1) a disease occurence with a frequency in excess of the expected frequency in an animal population during a given time interval (Stedman 2000) or (2) an outbreak of an infectious animal disease within a localized region (Kinne 1980). Epizootics may result from: (1) introduction of a new pathogen into a susceptible population, (2) increase in pathogen numbers or virulence, or (3) lowered resistance of the host population (Peters 1997). Corals and other marine organisms of the Caribbean have sustained epizootics in recent years. Two separate epizootics affecting the sea fans
Gorgonia ventalina and G. flabellum have occurred since the 1980s (Garzon-Ferreira \& Zea 1992, Nagelkerken et al. 1997b), and both have been attributed to ASP (Smith et al. 1996, Geiser et al. 1998). An epizootic affecting the long-spined sea urchin Diadema antillarum occurred in 1983 and resulted in catastrophic reductions in urchin populations (Lessios et al. 1984). WBD (Type I) and WPD epizootics, which began in the mid-1970s and the mid-1990s, respectively, have decimated populations of acroporid corals on Caribbean coral reefs (Gladfelter 1982, Bythell \& Sheppard 1993, Aronson \& Precht 1997, 2001, Aronson et al. 1998, Patterson et al. 2002).

\section{PROVING DISEASE CAUSATION}

Since the 19th century, it has been generally accepted that in order to prove disease causation by a biotic agent, Koch's postulates must be fulfilled (Koch 1882). Koch's postulates require that: (1) the putative pathogen be found in every diseased individual, (2) the putative pathogen be isolated from a diseased individual and grown in pure culture, and (3) the disease be induced in experimental organisms by transferring the pathogen from the culture (Koch 1882). A fourth postulate, that: (4) the same pathogen be isolated from the experimental organism after the disease develops, was later added to Koch's list but was not required by Koch himself. Limitations of the postulates were immediately apparent, and Koch was never able to fulfill his own formulation for disease causation for cholera or leprosy. The accepted etiologic agent of leprosy, Мусоbacterium leprae, remains unproven by fulfillment of Koch's postulates (Fredericks \& Relman 1996).

Although Koch's postulates have elucidated the etiologies of countless diseases, this method of proving disease causation has numerous limitations. Koch's third postulate cannot ethically be fulfilled for fatal diseases that exclusively affect humans (e.g. HIV). Koch's postulates cannot be fulfilled according to the strict definition of the procedure for diseases that: (1) are caused by unculturable bacteria, fungi, or viruses (2) are caused by a consortium of microorganisms, (3) are caused by abiotic stressors, (4) require a vector or a carrier state, (5) cause subclinical or latent infection, or (6) cause injury through systemic attack via virulence factors such as toxins (Fredericks \& Relman 1996, US EPA 2000). In addition, Koch's postulates ignore the classic paradigm of disease causation through pathogen interaction with host and environment. Fulfillment of Koch's postulates unequivocally demonstrates disease causation by a specific pathogen; however, failure to fulfill these postulates does not eliminate the possibility that: (1) the putative pathogen 
does in fact cause the disease, nor that (2) the suspected pathogen is a commensal organism (Fredericks \& Relman 1996).

Several scientists have formulated alternative postulates for disease causation that take into account the limitations of those established by Koch (Rivers 1937 , Huebner 1957, Hill 1965, Johnson \& Gibbs 1974, Evans 1976, Falkow 1988, Fredericks \& Relman 1996). These revisions of Koch's postulates address viral etiology (Rivers 1937, Huebner 1957, Johnson \& Gibbs 1974, Evans 1976), carcinogenesis (Evans 1976), antibody response (Huebner 1957, Evans 1976), epidemiology (Huebner 1957, Evans 1976), genetic diseases (Falkow 1988), abiotic diseases (US EPA 2000), and molecular techniques for determining disease causation (Fredricks \& Relman 1996).

When Koch's 19th century postulates cannot be fulfilled due to characteristics of a disease that may be attributed to the nature of its etiology or the mechanisms of disease causation, then 21st century techniques can be employed to identify disease-causing microbes (Fredricks \& Relman 1996, Ritchie et al. 2001). The genotype-based technique of $16 \mathrm{~S}$ and $18 \mathrm{~S}$ rRNA gene sequence amplification can be used to identify putative pathogens and to generate specific probes and primers for use with in situ nucleic acid hybridization. In situ hybridization identifies a putative pathogen within diseased tissues. Nucleic-acid amplification techniques are highly sensitive and may also target microbes that are insignificant to disease causation (e.g. commensals or contaminants). However, these techniques provide a means of associating putative pathogens with diseased tissues (Fredricks \& Relman 1996).

Limitations of Koch's postulates have quickly become evident in the emerging field of coral disease etiology. Koch's postulates have been successfully fulfilled for only 5 (WPL II, WPD, ASP, VSB, VCB) of the 18 coral diseases identified to date in the global oceans (Table 4; Kushmaro et al. 1996, 1997, 1998, 2001, Smith et al. 1996, Geiser et al. 1998, Richardson et al. 1998a,b, Rosenberg et al. 1998, Ben-Haim \& Rosenberg 2002, Patterson et al. 2002, Ben-Haim et al. 2003a,b, Denner et al. 2003). Attempts to fulfill Koch's postulates have been unsuccessful for other coral diseases. Although a microbial consortium, dominated by cyanobacteria, is widely accepted as the causal agent of BBD, Koch's postulates have not been, and technically cannot be, fulfilled for this disease. Koch's postulates assume that a single microorganism, which can be grown in pure culture, causes a disease. In the case of BBD, a microbial consortium is thought to be required to induce disease (Carlton \& Richardson 1995, Richardson et al. 1997). WBD II is always associated with Vibrio charcharia, but attempts to fulfill Koch's postulates with this bacterium have been unsuccessful to date (Ritchie \& Smith 1995a).

Molecular techniques have the potential to increase our knowledge of coral disease processes that cannot be understood through the use of 19th century criteria for disease causation (Ritchie et al. 2001, Bythell et al. 2002, Cooney et al. 2002, Frias-Lopez et al. 2002, 2003). Community DNA can be isolated from coral tissue or its associated surface mucopolysaccharide layer (SML). Both diseased and apparently healthy corals have a bacterial community associated with SML, and this bacterial community is known to shift under conditions of stress (e.g. disease and bleaching, Ritchie \& Smith 1995a,b). Total community DNA from SML and coral tissue can be isolated, amplified, cloned, and compared to known sequences in a database e.g. GenBank). A phylogenetic tree can then be constructed and used to identify the evolutionary relationships of putative pathogens. Although these molecular techniques do not prove disease causation, their rapid and broad screening can establish an association between potential pathogens and disease, aiding in understanding of the infectious disease processes (Ritchie et al. 2001). To make significant advances in understanding coral disease etiology, alternative criteria for disease causation, in addition to those postulated by Koch, need to be developed, utilized, and accepted by coral disease researchers.

\section{GLOBAL CORAL DISEASES}

\section{Black band}

Black band disease (BBD; Fig. 3A) affects corals worldwide (Rützler \& Santavy 1983, Antonius 1985a, 1988, Edmunds 1991, Carlton \& Richardson 1995, Littler \& Littler 1996, Miller 1996, Bruckner \& Bruckner 1997ab, Bruckner et al. 1997, Green \& Bruckner 2000, Al-Moghrabi 2001, Dinsdale 2002). BBD is characterized by a darkly pigmented microbial mat, which forms a band ( 1 to $30 \mathrm{~mm}$ wide and ca. $1 \mathrm{~mm}$ thick) that separates living tissue from recently denuded skeleton (Fig. 3A, Rützler \& Santavy 1983, Carlton \& Richardson 1995).

The microbial consortium that composes the band is dominated by a filamentous cyanobacterium, the identity of which has long been believed to be Phormidium corallyticum (Rützler \& Santavy 1983). However, recent studies utilized molecular techniques to characterize the BBD consortium, and, while a single cyanobacterium species was associated with the disease, this cyanobacterium was not a member of the genus Phormidium (Table 4; Cooney et al. 2002, Frias-Lopez et al. 2002, 2003). The $16 \mathrm{~S}$ rRNA gene sequencing 

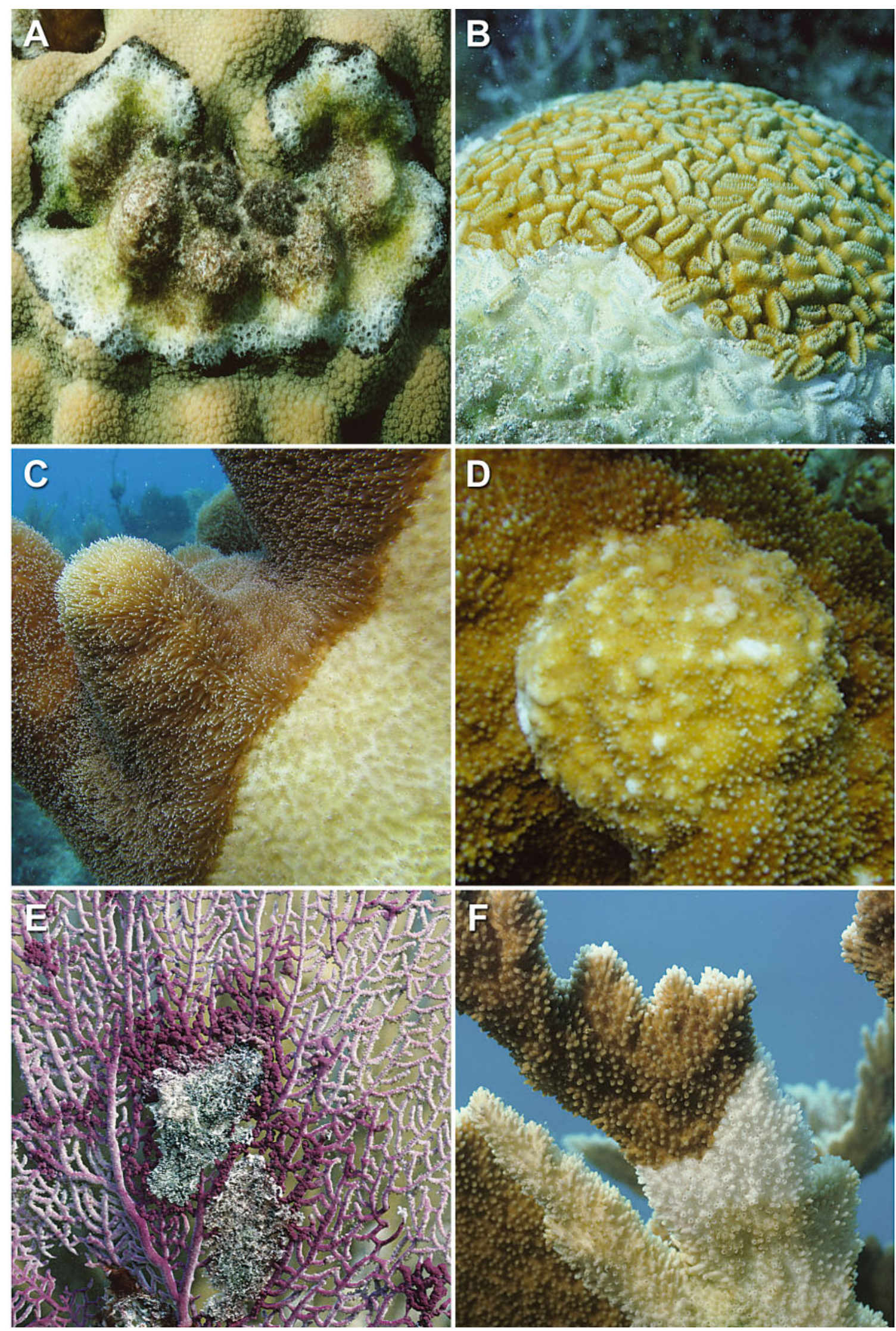
Fig. 3. Caribbean coral diseases: (A) black band (BBD) on Montastraea annularis complex; (B) white plague Type II (WPL II) on Dichocoenia stokesi; (C) WPL II on Dendrogyra cylindrus; (D) skeletal anomaly (SKA) on Acropora palmata; (E) aspergillosis (ASP) on Gorgonia sp.; (F) white band Type I (WBD I) on A. palmata. Photographs by J.W.P. and C.T.

identified at least 3 different taxa of cyanobacteria associated with BBD and determined that these taxa vary between the Caribbean and Indo-Pacific (FriasLopez et al. 2003). In the Caribbean, the BBD mat is dominated by an unidentified cyanobacterium most closely related to the genus Oscillatoria (Cooney et al. 2002, Frias-Lopez et al. 2003). In the Indo-Pacific, the BBD cyanobacterium is most closely related to the genus Trichodesmium (Frias-Lopez et al. 2003), and this genus (specifically $T$. tenue) has also been isolated from BBD mats in the Caribbean (Frias-Lopez et al. 2002).

Since 16S rRNA gene sequencing did not conclusively identify the cyanobacteria associated with BBD, but rather provided a most homologous match (FriasLopez et al. 2003), there is currently a discussion about the identitiy of the BBD cyanobacteria. It is important to note that the only 2 studies targeting the physiology of BBD cyanobacteria in the laboratory (Taylor 1983, Richardson \& Kuta 2003) both used cultures isolated from BBD that contained cyanobacteria identified as Phormidium corallyticum based on the morphology of this species (Rützler \& Santavy 1983). Future research will determine whether or not $P$. corallyticum is an essential component of the BBD microbial consortium.

Other microbes identified in the BBD consortium include sulfate-reducing bacteria Desulfovibrio spp. (Garrett \& Ducklow 1975, Schnell et al. 1996, Cooney et al. 2002), sulfide oxidizing bacteria Beggiatoa spp. (Ducklow \& Mitchell 1979b), a multitude of heterotrophic bacteria (Garrett \& Ducklow 1975, Cooney et al. 2002, Frias-Lopez et al. 2002), and a marine fungus (Ramos-Flores 1983). Two molecular studies carried out to investigate BBD (Cooney et al. 2002, Frias-Lopez et al. 2002) each found over 50 bacterial species associated with BBD. These included a wide assortment of proteobacteria, Cytophega sp., and an $\alpha$-proteobacterium closely related to the pathogen that causes juvenile oyster disease. The disease consortium, and not a single microorganism alone, is thought to be required for disease causation (Carlton \& Richardson 1995, Richardson et al. 1997). Koch's postulates have not been fulfilled with any component of the consortium (Carlton \& Richardson 1995).

BBD affects 19 (of 66) Caribbean shallow-water scleractinian species (Table 2; Rützler et al. 1983, Kuta \& Richardson 1996, Garzón-Ferreira et al. 2001, Porter et al. 2001, Wheaton et al. 2001) and 45 (of approximately 400) Indo-Pacific scleractinian species (Table 3; Antonius 1985a,b, Miller 1996, Green \& Bruckner 2000, Al-
Moghrabi 2001, Riegl 2002, Frias-Lopez et al. 2003). Six Caribbean gorgonian species are also affected by BBD (Table 2; Antonius 1981, 1985b, Feingold 1988). Caribbean corals most susceptible to BBD include Diploria strigosa, D. labyrinthiformis, Montastraea annularis, M. cavernosa, M. faveolata, M. franksi and Colpophyllia natans (Antonius 1981, Ramos-Flores 1983, Rützler et al. 1983, Kuta \& Richardson 1996). These corals are massive species and the dominant reef-builders. Acropora cervicornis, A. prolifera, and Porites porites appear resistant to BBD infections (Antonius 1981). BBD was recently reported affecting A. palmata in the Colombian Caribbean (GarzónFerreira et al. 2001). Prior to this report A. palmata was thought to be resistant to the disease. While BBD is rarely reported on acroporids in the Caribbean, this genus is among the most susceptible to BBD on the Great Barrier Reef, Australia (Miller 1996, Dinsdale 2002). A BBD epizootic affecting faviid corals occurred at Looe Key Reef, Florida in 1986 (Peters 1993). BBD most often affects fewer than $1 \%$ of coral colonies on any reef area at any one time (Edmunds 1991, Kuta \& Richardson 1996), but the susceptibility of major frame-building species greatly enhances the threat that BBD poses to the reef community.

Infection with BBD usually begins on upper surfaces of a coral colony (Antonius 1981) as a small darklypigmented patch (1 to $2 \mathrm{~cm}$ diameter). The patch quickly forms a ring, the circumference of which rapidly increases as the band migrates horizontally across the coral. As the microbial mat migrates, it kills all tissue and leaves behind bare skeleton (Antonius 1981, Carlton \& Richardson 1995). Horizontal movement of the band is greatest at the front of the band (adjacent to living tissue) during the day, and at the back of the band (adjacent to dead skeleton) at night. This migration pattern results in a widening of the microbial mat during the day and a contraction at night (Richardson 1996).

BBD progresses at an average rate of $3 \mathrm{~mm} \mathrm{~d}^{-1}$, but is capable of advancing up to $1 \mathrm{~cm} \mathrm{~d}^{-1}$ (Antonius 1981, 1985a, Edmunds 1991, Carlton \& Richardson 1995). This rapid rate of tissue loss, coupled with the slow growth rate of scleractinian corals, denudes living coral tissue quickly and allows for complete colony mortality. However, BBD may disappear before complete colony mortality occurs (Carlton \& Richardson 1995). This cessation of BBD most often occurs with the onset of lower seawater temperatures (Carlton \& Richardson 1995). 
BBD has been widely reported as a seasonal phenomenon, with most active infections occurring during late summer and fall, and cessation occurring during winter (Antonius 1981, 1985a, Edmunds 1991, Carlton \& Richardson 1995). Seasonality of BBD is related to summer seawater temperatures in excess of $25^{\circ} \mathrm{C}$ (Rützler et al. 1983, Edmunds 1991, Kuta \& Richardson 2002, Richardson \& Kuta 2003). When BBD disappears in the winter, remaining living coral tissue survives (Antonius 1981, Carlton \& Richardson 1995). However, seasonal reappearance of warm seawater coincides with observations of reinfection, and reinfection makes complete colony mortality possible (Carlton \& Richardson 1995, Kuta \& Richardson 1996). It is important to note that BBD has been reported year-round, even at seawater temperatures as low as $20^{\circ} \mathrm{C}$ (Kuta \& Richardson 1996), and that the cyanobacteria associated with $\mathrm{BBD}$ are capable of photosynthesis at temperatures as low as 18 and $20^{\circ} \mathrm{C}$ (Taylor 1983, Richardson \& Kuta 2003).

BBD has been proposed to be correlated with other environmental and physiological stressors, including terrestrial runoff (Littler \& Littler 1996, Bruckner et al. 1997, Frias-Lopez et al. 2002), coral overgrowth by algae (Bruckner et al. 1997), eutrophication (Antonius 1981, 1985a, Kuta \& Richardson 2002), and pollution (Antonius 1985a, Al-Moghrabi 2001), including human fecal contamination (Frias-Lopez et al. 2002, Table 5). However, very little quantitative data, and no definitive results, have supported a positive correlation. Pollution has been implicated in extending depth range, frequency, and severity of BBD (Antonius 1985a). BBD has been frequently reported from shallow depths (Rützler et al. 1983, Antonius 1985a, Kuta \& Richardson 2002) and reefs with low coral species diversity (Bruckner \& Bruckner 1997b, Bruckner et al. 1997, Kuta \& Richardson 2002).

The mechanism by which BBD kills coral tissue is directly linked to dynamics of the microbial mat community, which produces a vertical zonation of oxygen and sulfide microenvironments that migrates on a diel basis. The dominant constituent of BBD, the cyanobacteria, forms the scaffolding of the band and is always present throughout the band. The cyanobacteria undergo oxygenic photosynthesis during the day, producing an oxygen supersaturated oxic zone in the top $\frac{1}{2}$ to $\frac{2}{3}$ of the band. The cyanobacteria adapt to the high sulfide environment of the disease band by performing oxygenic photosynthesis in the presence of sulfide (Richardson \& Kuta 2003). The anoxic base of the band is dominated by sulfate-reducing bacteria Desulfovibrio spp. The oxic/anoxic interface contains sulfide-oxidizing bacteria Beggiatoa spp., and this zone migrates vertically on a diel basis in response to changes in light intensity (Viehman \& Richardson
2002) and photosynthetic activity occurring within the band (Carlton \& Richardson 1995, Richardson et al. 1997). Under low light conditions (e.g. shade, darkness) the surface community of BBD is dominated by cyanobacteria, but when light intensity increases, Beggiatoa spp. migrate to the band surface (Viehman \& Richardson 2002). At night, in absence of oxygen production, Desulfovibrio spp. undergo sulfate reduction, increasing sulfide concentrations in the band. As a result, sulfide is present throughout the band at night and the oxic/anoxic interface migrates to the band surface (Carlton \& Richardson 1995, Richardson et al. 1997).

Presence of sulfide and anoxia at the base of the band (adjacent to coral tissue) is thought to be the cause of tissue lysis and death (Carlton \& Richardson 1995). BBD-induced coral mortality presumably releases inorganic nutrients $\left(\mathrm{NH}_{4}{ }^{+}\right.$and $\left.\mathrm{PO}_{4}{ }^{3-}\right)$ that support cyanobacterial photosynthesis. Furthermore, because the disease band directly overlies coral tissue that is being degraded, nutrients supplied by tissue mortality diffuse directly into the band, providing concentrated nutrients to the microbial consortium, and fueling their growth and reproduction (Carlton \& Richardson 1995). This process of tissue death may serve as the source for elevated nitrite levels associated with seawater immediately surrounding BBDaffected corals (Kuta \& Richardson 2002).

The mechanism of BBD transmission remains unknown. However, BBD may be infectious (Edmunds 1991, Kuta \& Richardson 1996) and transmitted in the water column (Kuta \& Richardson 1996, Bruckner et al. 1997). Sediment patches on the surfaces of apparently healthy corals may serve as reservoirs of the cyanobacteria associated with BBD (Richardson 1997).

Disease signs similar to BBD were reported in 1983 (Rützler et al. 1983) and documented as a new disease termed red band (Richardson 1993). Red band reportedly affects Gorgonia ventalina in Belize, Puerto Rico and the Florida Keys (Santavy \& Peters 1997), and Montastraea annularis and M. faveolata in the Colombian Caribbean (Garzón-Ferreira et al. 2001). Red band is characterized by a red-brown to brown-black microbial mat that forms a migrating band that separates recently denuded skeleton from living tissue (Santavy \& Peters 1997). The condition was considered not to be BBD because Phormidium corallyticum, accepted at the time to be the dominant component of the BBD consortium, was not present in red band (Rützler et al. 1983). Instead, red band was dominanted by other species of cyanobacteria, identified as Schizothrix calcicola, S. mexicana (Rützler et al. 1983) and Oscillatoria spp. (Richardson 1993). The RBD microbial consortium may include other cyanobacteria, heterotrophic bacteria, the sulfur-oxidizing bacterium Beggiatoa sp., and the nematode Araeolaimus sp. (Santavy \& 
Peters 1997). The recent discovery that BBD is associated with at least 3 different taxa of cyanobacteria (Frias-Lopez et al. 2003) and the lack of new reports of red band disease since the early 1990s, suggest that red band is not a distinct disease, but rather BBD.

\section{White plague}

White plague (WPL; Fig. 3B,C) has affected Caribbean and Indo-Pacific corals since the late 1970s (Dustan 1977, Richardson et al. 1998a) and early 1980s (Antonius 1985a), respectively. In the Caribbean, the disease reported in the 1970s has been renamed WPL I to distinguish this condition from 2 new diseases with similar disease signs: WPL II (Richardson et al. 1998a) and WPL III (Richardson et al. 2001). WPL II is an infectious biotic disease (Richardson et al. 1998a) caused by a new genus and species of bacterium, Aurantimonas coralicida (Table 4; Richardson et al. 1998b, Denner et al. 2003). Pathogenesis and transmission of WPL II are not understood. Histopathology of WPL I affected tissues shows necrosis at lesion boundaries (Peters 1984, Bythell et al. 2002) accompanied by dense clusters of coccoid bacteria that do not resemble the rod-shaped A. coralicida from WPL II infections (Bythell et al. 2002). Similarly, 16S rDNA sequencing indicates that A. coralicida is not associated with a WPL-like disease affecting Caribbean corals (Pantos et al. 2003). These studies suggest that there is indeed more than one etiologic agent associated with the various WPL diseases in the Caribbean. The causal agent(s) of WPL I and III are unknown.

In the Indo-Pacific, WPL-like (WPL-L) disease signs have been reported. Authors that documented WPL-L disease in the Indo-Pacific referred to the disease as WBD (Antonius 1985a, Coles 1994, Riegl 2002). Species affected and disease signs reported for the IndoPacific (Antonius 1985a, Coles 1994) are indicative of a WPL-L disease. In the future, Indo-Pacific researchers must distinguish between WPL-L and WBD-like diseases, which are characterized, respectively, by a sharp line of tissue loss that progresses across a coral colony and by a ring of tissue loss that progresses up or down acroporid coral branches. WPL-L disease affects 38 Indo-Pacific scleractinian species (Table 3; Antonius 1985a, Coles 1994, Riegl 2002).

WPL I progresses slowly ( $3.1 \mathrm{~mm} \mathrm{~d}^{-1}$ maximum) and is characterized by a sharp line of tissue loss where healthy tissue is immediately adjacent to recently denuded skeleton (Fig. 3B,Ci Dustan 1977). WPL I affects at least 13 Caribbean scleractinian species (Table 2; Dustan 1977, Richardson et al. 1998a).

WPL II progresses rapidly ( $2 \mathrm{~cm} \mathrm{~d}^{-1}$ maximum) and is characterized by a sharp line of disease progression. At times a narrow band ( 2 to $3 \mathrm{~mm}$ ) of bleached tissue separates healthy tissue and bare skeleton, but more commonly the disease line appears the same as for WPL I, i.e. healthy tissue is immediately adjacent to recently denuded tissue (Richardson et al. 1998a,b). Another distinguishing characteristic of WPL II is that infection most often begins at the base of the coral colony and progresses upward in a concentric ring around the entire colony (Richardson et al. 1998a,b). Three major epizootics of WPL II have been reported in South Florida since the mid-1990s (Richardson et al. 1998a). The number of species affected by WPL II is increasing. In 1995, Richardson et al. (1998a,b) reported 17 species of scleractinian corals affected on reefs in the Florida Keys, and by 2000 this number had increased to 32 species (Weil et al. 2002). Highest disease prevalence of WPL II has been recorded for Dichocoenia stokesi, with mortality as high as 38\% (Richardson et al. 1998a).

WPL III was first documented in 1999 in the northern Florida Keys. WPL III appears to exclusively affect large colonies (3 to $4 \mathrm{~m}$ diameter) of Colpophyllia natans and Montastraea annularis (Table 2). Tissue loss attributed to WPL III is extremely rapid and greatly exceeds loss rates attributed to WPL I and WPL II (Richardson et al. 2001).

Surveys of WPL prevalence conducted in Puerto Rico (Bruckner \& Bruckner 1997a) and St. Lucia, West Indies (Nugues 2002) did not distinguish type. However, based on slow rate of disease progression $\left(1.3 \mathrm{~mm} \mathrm{~d}^{-1}\right.$ maximum) measured in St. Lucia (Nugues 2002) and rapid disease progression $\left(1.4 \mathrm{~cm} \mathrm{~d}^{-1}\right.$ maximum) measured in Puerto Rico (Bruckner \& Bruckner 1997a) it is likely that the diseases surveyed were WPL I and II, respectively. Highest disease prevalence was recorded for Diploria labyrinthiformis (47\% of colonies affected) in Puerto Rico (Bruckner \& Bruckner 1997a) and for Montastraea faveolata $(19 \%$ of colonies affected) and Colpophyllia natans (13\% of colonies affected) in St. Lucia (Nugues 2002).

Nugues (2002) observed diseased individuals of 4 scleractinian species, Isophylastrea rigida, Montastraea faveolata, Mussa angulosa, and Mycetophyllia sp., not yet documented as susceptible to WPL I (Table 2). Surveys conducted within the FKNMS documented WPL (type not determined) on 14 additional species (Table 2; Porter et al. 2001).

\section{Shut-down reaction}

Shut-down reaction (SDR) is a condition that most often affects corals contained in aquaria and is rarely observed in natural coral reef environments. SDR occurs only on wounded corals (e.g. predation, diver 
contact) and is always associated with abiotic environmental stressors (e.g. temperature extremes, sedimentation, Table 5; Antonius 1977). SDR begins at and radiates from the interface between wound and healthy tissue. Tissue is sloughed off the affected colony at the rapid rate of $10 \mathrm{~cm} \mathrm{~h}^{-1}$. Once SDR is triggered, complete colony mortality is inevitable. SDR is contagious, indicating presence of a pathogen, and can be both directly and indirectly transmitted from an infected colony to a stressed, but otherwise apparently healthy colony, via physical contact between neighboring colonies and water transport, respectively (Antonius 1977). SDR cannot be transmitted to unstressed coral colonies (Antonius 1977).

SDR has been experimentally induced in aquaria for 6 Caribbean scleractinian species (Table 2; Antonius 1977). In the Caribbean, SDR has been reported affecting only 3 individual coral colonies in the field; the 2 species affected were Montastraea annularis and Acropora cervicornis (Table 2; Antonius 1977). Prior to recent reports of SDR in the Red Sea (species affected not reported, Antonius \& Riegl 1997, 1998), new cases of the condition had not been documented since the first report in the late 1970s (Antonius 1977).

\section{Skeletal anomalies}

Skeletal anomalies include tumors, galls, nodules, and other abnormalities of coral tissue and skeleton. Skeletal anomalies of scleractinian corals have been observed on reefs throughout the world including the Florida Keys (Peters et al. 1986), Netherlands Antilles (Bak 1983), Hawaii (Squires 1965, Cheng \& Wong 1974, Hunter \& Peters 1993 Grygier \& Cairns 1996, Aeby 1998), Guam and Enewetak (Cheney 1975), Oman (Coles \& Seapy 1998), Japan (Yamashiro et al. 2000), and the Great Barrier Reef, Australia (Loya et al. 1984).

A tumor is an abnormal tissue proliferation (Sinderman 1990) and, in corals, is often associated with an abnormal skeletal growth (Yamashiro et al. 2000). Tumors result from neoplasia, hyperplasia, or hypertrophy. Neoplasia (neoplasm) is uncontrolled cell proliferation. Hyperplasia and hypertrophy are nonneoplastic controlled cell proliferation and nonneoplastic increase in cell size, respectively (Sinderman 1990). The terms tumor and neoplasia are considered by many to be synonymous (Stedman 2000).

The first suspected neoplasm of a scleractinian coral was documented in 1965 on Madrepora kauaiensis in the Hawaiian Islands (Table 3, Squires 1965). This condition, also observed on $M$. oculata (Table 3), has recently been reinterpreted as a polyp hypertrophy characterized by gall formation (i.e. a parasite-induced proliferation of tissues, Grygier \& Cairns 1996). These lesions develop on Madrepora spp. when the crustacean Petrarca madreporae, an obligate endoparasite of corals, invades a normal coral polyp as a larva and matures within the polyp, causing development of an enlarged (hypertrophied) corallite with abnormal septae (Table 4; Grygier \& Cairns 1996).

Other skeletal anomalies have been attributed to interactions with foreign organisms in the skeleton (Table 4). Porites compressa and P. lobata in Kaneohe Bay, Oahu, Hawaii develop grossly visible pink nodules in response to the encystment of the digenetic trematode Podocotyloides stenometra within the tentacles of the coral polyps (Table 3; Cheng \& Wong 1974, Aeby 1998). The scleractinian corals P. lobata, P. lutea, Manicina areolata, and Montastraea cavernosa can detect invasion by endolithic fungi and respond by surrounding the site of fungal penetration within a layer of thickened calcium carbonate produced by hypertrophied calicoblasts (Tables 3 \& 4; Le ChampionAlsumard et al. 1995, Ravindran et al. 2001, E. C. Peters pers. comm.). However, this defense mechanism fails to hinder fungal advancement, and, as hyphae penetrate the layer of calcium carbonate repair, the coral repeats the process, resulting in a calcareous skeletal protuberance composed of a number of carbonate layers (Le Champion-Alsumard et al. 1995). Nodules on the gorgonian coral Gorgonia ventalina are attributed to both infection with Aspergillus sydowii, the causal agent of aspergillosis (Dube et al. 2002), and to infestation with filamentous green algae of the Order Siphonales (Tables $2 \& 4$; Morse et al. $1977,1981)$. The algal nodules are hyperplasias of the axis epithelial cells that produce the endoskeletal gorgonin. Amoebocytes infiltrate the associated mesoglea and encapsulate the algal filaments (Morse et al. 1977, 1981). Aspergillosis-associated nodule formation may be a defense mechanism that sequesters fungal hyphae and limits spread of infection (Smith et al. 1998). Nodules on the gorgonian corals Pseudoplexaura spp. are the result of skeletal encapsulation of the marine microalgae Entocladia endozoica (Tables 2 \& 4; Goldberg et al. 1984).

Peters et al. (1986) and Coles \& Seapy (1998) described the only known true neoplasms (tumors) of corals. Peters et al. (1986) observed neoplasms, termed calicoblastic epitheliomas, on Acropora palmata in the Florida Keys (Table 2). These calicoblastic epitheliomas result from proliferation of calicoblasts and associated tissues and are characterized by raised (up to $1 \mathrm{~cm}$ high), irregularly shaped, smooth, white lumps that develop on all parts of the coral colony. Mean growth rate of tumors is $0.12 \mathrm{~mm} \mathrm{~d}^{-1}$ or 25 to $44 \mathrm{~mm}$ $\mathrm{yr}^{-1}$ (Peters et al. 1986). Similar calicoblastic epitheliomas affect $A$. valenciennesi and $A$. valida in the Gulf of Oman, Indian Ocean (Table 3; Coles \& Seapy 1998). 
Coral skeletal anomalies are characterized by: (1) thinning of coral tissue covering anomalies (Peters et al. 1986, Coles \& Seapy 1998), (2) increased porosity of coral skeleton (Peters et al. 1986, Coles \& Seapy 1998, Yamashiro et al. 2000), (3) loss of mucous secretory cells and nematocysts (Peters et al. 1986, Coles \& Seapy 1998), (4) loss of zooxanthellae (Bak 1983, Peters et al. 1986, Coles \& Seapy 1998, Yamashiro et al. 2000), (5) loss, reduction, or degeneration of normal polyp structures (Bak 1983, Peters et al. 1986, Coles \& Seapy 1998, Yamashiro et al. 2000), and (6) reduced fecundity (Yamashiro et al. 2000).

Skeletal anomalies pose a serious threat to affected corals. Loss of the primary defense mechanism, mucous secretory cells, inhibits removal of foreign material from the coral surface, contributing to cell death and increasing susceptibility to invasion by filamentous algae. Porous skeletons may be more susceptible to storm-related damage (Peters et al. 1986). Loss of zooxanthellae reduces fecundity, skeletal growth, calcification rates, and nutrition (Bak 1983, Porter et al. 1989, Brown 1997a). Polyp destruction limits reproductive capacity (Peters et al. 1986, Yamashiro et al. 2000).

Skeletal anomalies (SKA; Fig. 3D) affect 16 Caribbean (Table 2) and 24 Indo-Pacific (Table 3) scleractinian species, 1 Caribbean hydrozoan, and at least 5 species of Caribbean gorgonians (Table 2; Squires 1965, Cheney 1975, Morse et al. 1977, 1981, Bak 1983, Goldberg et al. 1984, Loya et al. 1984, Peters et al. 1986, Hunter \& Peters 1993, Le Champion-Alsumard et al. 1995, Grygier \& Cairns 1996, Coles \& Seapy 1998, Green \& Bruckner 2000, Yamashiro et al. 2000, Ravindran et al. 2001, Dube et al. 2002). Acroporids appear to be the most susceptible to neoplasia (Peters et al. 1986, Coles \& Seapy 1998), and this may be due to the rapid growth rates of this genus (Peters et al. 1986). Acropora palmata is capable of linear extension rates as high as 47 to $99 \mathrm{~mm} \mathrm{yr}^{-1}$ (Gladfelter et al. 1978).

With the exception of microorganism-induced nodule or gall formation (Cheng \& Wong 1974, Morse et al. 1977, 1981, Goldberg et al. 1984, Le Champion-Alsumard et al. 1995, Grygier \& Cairns 1996, Aeby 1998, Ravindran et al. 2001, Dube et al. 2002), the etiology of coral skeletal anomalies is unknown (Peters et al. 1986, Coles \& Seapy 1998, Yamashiro et al. 2000). Parasitic and commensal organisms have been ruled out as potential causal agents of the skeletal anomalies described by Peters et al. (1986) in the Florida Keys and by Yamashiro et al. (2000) in Japan. Solar UV radiation has been hypothesized as a possible initiator of neoplasia formation (Table 5; Peters et al. 1986, Coles \& Seapy 1998).

\section{CARIBBEAN CORAL DISEASES}

\section{Aspergillosis}

Mass mortalities of the sea fans Gorgonia ventalina and G. flabellum were reported throughout the Caribbean during the 1980s (Garzón-Ferreira \& Zea 1992). A second epizootic affecting Gorgonia spp. began in 1995 (Nagelkerken 1997ab, Slattery 1999), which was less virulent but more widespread than the 1980s epizootic (Nagelkerken 1997a,b).

Both epizootics have been attributed to the fungus Aspergillus sydowii (Table 4; Smith et al. 1996, Geiser et al. 1998). Aspergillus disease, termed aspergillosis (ASP; Fig. 3E), destroys living tissue and degrades skeletal framework (Nagelkerken et al. 1997b). In addition to Gorgonia ventalina and G. flabellum, ASP signs have been observed on 6 additional gorgonian species from 5 genera (Kim et al. 2000b, Weil et al. 2002; Table 2). However, Koch's postulates have only been fulfilled, establishing $A$. sydowii as the causative agent, for disease cases affecting $G$. ventalina and $G$. flabellum (Smith et al. 1996).

ASP lesions are characterized by recession of rind tissue (coenenchyme) exposing the internal axial skeleton. Aspergillus sydowii hyphae are embedded in living tissue at the receding edge of the lesion (Smith et al. 1996). Lesions are often circumscribed by a purple halo indicative of an abundance of purple sclerites (Kim et al. 1997, Smith et al. 1998, Slattery 1999). Purple sclerite-dense nodules often erupt on affected sea fans (Kim et al. 1997, Smith et al. 1998, Dube et al. 2002). Sclerite recruitment and nodule formation may be methods of defense that sequester fungal hyphae and limit spread of infection (Smith et al. 1998). Mechanisms by which $A$. sydowii produces tissue degradation and nodule formation remain unknown, but virulence of the pathogen is known to increase with elevated seawater temperatures $\left(30^{\circ} \mathrm{C}\right.$, Table 5; Alker et al. 2001).

The genus Aspergillus is not commonly found in marine environments and most often inhabits terrestrial soils. However, Aspergillus spp. can easily cope with the salinity of seawater (Kendrick et al. 1982) and have been isolated from marine environments (Muntanola-Cvetkovic \& Ristanovic 1980, Kendrick et al. 1982, Ravindran et al. 2001). A. sydowii has been shown to bioerode living stony corals (Kendrick et al. 1982).

Aspergillus sydowii is a terrestrial fungus. Delivery of A. sydowii to the marine environment may be associated with either local sediment runoff (Smith et al. 1996) or long distance transport (Table 5, Shinn et al. 2000). If local runoff is the source, then ASP may be linked to anthropogenic disturbance. Shinn et al. 
(2000) hypothesize that $A$. sydowii, and perhaps other coral disease-causing pathogens, are transported to the western Atlantic in African dust air masses. A. sydowii has been cultured from spores collected in the US Virgin Islands during African dust storm events. These A. sydowii isolates, when inoculated onto healthy sea fans, produced ASP signs (Weir et al. in press).

Terrestrial sources are a possible mode of primary transmission of Aspergillus sydowii hyphae and/or spores to unaffected sea fans in the marine environment. A. sydowii germinates but does not sporulate on sea fans. Hyphae must break free from an infected gorgonian and reach the surface of the water to produce spores (G. W. Smith pers. comm.). Secondary transmission of ASP from infected to uninfected sea fans may occur through: (1) direct physical contact with an infected individual, i.e. a diseased sea fan may brush against a close neighbor (Smith et al. 1996, Jolles et al. 2002), (2) transport of fungal hyphae in the water column (Jolles et al. 2002), or (3) transport of fungal spores (produced at the sea surface from hyphae released from diseased sea fans) in the water column (G. W. Smith pers. comm.).

Incidence and prevalence of ASP are greater at protected than at exposed sites and increase with depth in areas with low to moderate wave action, indicating that the more frequent mechanical swaying of colonies that occurs in shallow and more exposed areas may decrease sea fan susceptibility to disease (Nagelkerken 1997a). ASP is prevalent in the Florida Keys, affecting $43 \%$ of Gorgonia ventalina colonies Keyswide (Kim \& Harvell 2002). Poor water quality (i.e. increased turbidity and increased chl a) may play a role in the impact of ASP on sea fan populations (Table 5). Kim \& Harvell (2002) found that severity of ASP in the Florida Keys was greatest near the city of Key West. With approximately 25500 residents and a high seasonal influx of tourists, Key West is by far the most populous town in the Florida Keys (US BOC 2000). Runoff of nutrients and pollutants into the marine environment is likely higher near Key West than in other less populated areas in the Florida Keys.

\section{White band}

White band disease (WBD; Fig. 3F) has affected Caribbean scleractinian corals since the late 1970s (Antonius 1985a, Bythell \& Sheppard 1993). The disease, as first described by Gladfelter (1982), has been renamed WBD I to distinguish the condition from WBD II (Ritchie \& Smith 1998). WBD I and II exclusively affect branching acroporid corals. While WBD I affects both Acropora palmata and A. cervicornis Caribbean- wide (Gladfelter 1982, Peters 1984), WBD II has been reported only from the Bahamas, exclusively affecting A. cervicornis (Ritchie \& Smith 1998; Table 2).

WBD Type I has been implicated as the principal cause of mass mortalities of Acropora cervicornis and A. palmata that occurred in the 1980s and 1990s (Gladfelter 1982, Bythell \& Sheppard 1993, Aronson \& Precht 1997, 2001, Aronson et al. 1998, 2002). On most reefs, loss of acroporids was accompanied by an ecological phase shift from a coral-dominated to an algaldominated reef (Hughes 1994). However, on the Belizean Barrier Reef, the grazing urchin Echinometra viridis consumed fleshy and filamentous macroalgae and allowed for a wide scale (at least $500 \mathrm{~km}^{2}$ ) coral community shift (Aronson et al. 2002). Following the WBD epizootic of the late-1980s, the previously dominant coral A. cervicornis was replaced by the thin-leaf lettuce coral Agaricia tenuifolia (Aronson \& Precht 1997, Aronson et al. 2002). Examination of the fossil record indicates that the wide-scale Acropora-toAgaricia shift is unprecedented in the last $3800 \mathrm{yr}$ (Aronson \& Precht 1997, 2001, Aronson et al. 2002). This evidence suggests that WBD is an emergent disease and not a natural cyclic phenomenon that has occurred on Caribbean reefs in the past.

WBD I progresses rapidly ( $2 \mathrm{~cm} \mathrm{~d}^{-1}$ maximum) and has the potential to cause extensive mortality (Antonius 1981, Gladfelter 1982, Peters et al. 1983). The disease is characterized by a white band of recently denuded skeleton adjacent to a necrotic front of normally pigmented living tissue (Fig. 3F; Gladfelter 1982, Peters et al. 1983). WBD I develops at the base of a coral colony or branch and progresses upward toward branch tips in a concentric ring (Gladfelter 1982).

WBD II was first documented in 1993 in the Bahamas (Ritchie \& Smith 1995a, Ritchie \& Smith 1998). WBD II is distinguished from WBD I by a band $(2$ to $20 \mathrm{~cm}$ wide) of living bleached tissue separating denuded skeleton from normally pigmented tissue. The bleaching of the tissue progresses more rapidly than does the margin of necrotic tissue and can arrest, allowing the necrotic margin to catch up to normal tissue. When this occurs, WBD II resembles WBD I (Ritchie \& Smith 1998) and the 2 diseases cannot be distinguished from a single observation in the field. Like WBD I, WBD II can develop at the base of a coral colony and progress upward, but WBD II is also capable of developing at tips of branches and progressing downward. When the disease begins at branch tips, tissue loss can be accompanied by skeletal degradation, i.e. dissolution and loss of branch tips (Ritchie \& Smith 1998).

The causative agents of WBD I and II are unknown, however, efforts have been made to determine etiologies of these conditions. Tissues of WBD I-diseased and apparently healthy Acropora palmata and A. cer- 
vicornis at St. Croix, US Virgin Islands and at Bonaire were found to contain Gram-negative bacterial aggregates. Aggregates were more abundant in diseased corals than in apparently healthy corals. However, other apparently healthy and diseased acroporids do not contain aggregates (Peters et al. 1983). Examination of A. cervicornis from the Bahamas and the Florida Keys revealed WBD I-affected colonies both with and without bacterial aggregates (Peters 1984). Thus, the role of bacterial aggregates in WBD I is uncertain. Histopathology of WBD I tissues shows no signs of necrosis or clustering of microorganisms (Peters et al. 1983, Bythell et al. 2002).

WBD II is always associated with the bacterium Vibrio charcharia (Table 4; Ritchie \& Smith 1995a). Attempts to fulfill Koch's postulates with $V$. charcharia were unsuccessful, and therefore the significance of the bacterium to the etiology of WBD II remains unknown.

\section{White pox}

White pox disease (WPD; Fig. 4A,B), also termed acroporid serratiosis (Patterson et al. 2002) and patchy necrosis (Bruckner \& Bruckner 1997a), was first documented in 1996 on reefs off Key West, Florida (Holden 1996). WPD has since been observed throughout the Caribbean (Porter et al. 2001, Rodríquez-Martínez et al. 2001, Santavy et al. 2001, Patterson et al. 2002). The disease exclusively affects Acropora palmata (Table 2), and is caused by the common fecal enterobacterium Serratia marcescens (Table 4; Patterson et al. 2002).

Serratia marcescens is a Gram-negative bacterium classified as a coliform and a member of the Enterobacteriaceae family. It is found in feces of humans and other animals and in water and soil (Grimont \& Grimont 1994). The prevalence of $S$. marcescens in the marine environment is unknown. However, this bacterium has been found in the marine environment in sewage-polluted estuaries. For example, S. marcescens has been linked to disease of white perch Morone americanus in the sewage-polluted Back River, Maryland (Baya et al. 1992).

Identification of Serratia marcescens as a coral pathogen marked the first time that a common member of the human gut microbiota was shown to be a marine invertebrate pathogen. While $S$. marcescens is ubiquitous, its noted association with human hosts prompts speculation that improperly treated sewage may be associated with white pox disease in corals. Human enteric bacteria and viruses are prevalent in coral SML and other marine environments of the Florida Keys (Griffin et al. 1999, Lipp et al. 2002). The origin and pathogenic mechanisms of the WPD pathogen are unknown (Patterson et al. 2002).
Coral colonies affected by WPD are characterized by irregularly shaped distinct white patches of recently exposed skeleton surrounded by a necrotic front of normally pigmented living tissue (Fig. 4B). Lesions range in area from a few square centimeters to $>80 \mathrm{~cm}^{2}$ and develop simultaneously on all surfaces of the coral colony (Fig. 4A; Patterson et al. 2002). Lesions exhibit tissue loss along the perimeter and increase in area as tissue is lost from the leading edge of infection. Rate of tissue loss is rapid, averaging $2.5 \mathrm{~cm}^{2} \mathrm{~d}^{-1}$, and is greatest during periods of seasonally elevated temperature and rainfall (Table 5). WPD is highly contagious, with nearest neighbors most susceptible to infection (Patterson et al. 2002). The disease spread rapidly within and between reefs in the Florida Keys during the mid-1990s (Porter et al. 2001, Patterson et al. 2002).

WPD has been implicated as the principal cause of mass mortality of Acropora palmata within the FKNMS (Patterson et al. 2002). Between 1996 and 2002, average loss of A. palmata Keys-wide was $87 \%$ (Fig. 1; Patterson et al. 2002, Sutherland \& Ritchie in press). Losses of A. palmata at Eastern Dry Rocks Reef, FL $\left(24^{\circ} 27.715^{\prime} \mathrm{N}, 81^{\circ} 50.801^{\prime} \mathrm{W}\right)$ between 1994 and 2002, and at Looe Key Reef, FL $\left(24^{\circ} 33^{\prime} \mathrm{N}, 81^{\circ} 24^{\prime} \mathrm{W}\right)$ between 1983 and 2000, were 97 and $93 \%$, respectively (Miller et al. 2002, Patterson et al. 2002, Sutherland \& Ritchie in press). These severe population declines of the coral community's most important primary producer and shallow water framework builder have led to the identification of $A$. palmata as a candidate for inclusion on the Endangered Species List (Diaz-Soltero 1999). Diseases of acroporid corals (WPD and WBD) are changing the composition, structure, and function of Caribbean coral reef ecosystems (Hughes 1994, Aronson \& Precht 1997, 2001, Aronson et al. 2002, Patterson et al. 2002).

\section{Yellow blotch/band}

Yellow blotch/band (YBL; Fig. 4C,D) disease has been reported throughout the Caribbean since 1994 (Santavy \& Peters 1997, Santavy et al. 1999, Cervino et al. 2001, Garzón-Ferreira et al. 2001, Toller et al. 2001, Weil et al. 2002). YBL affects 9 scleractinian coral species (Table 2; Garzón-Ferreira et al. 2001), but most often affects Montastraea annularis (Cervino et al. 2001). The causal agent of YBL is unknown.

YBL lesions are characterized by circular to irregularly shaped patches (Fig. 4C) or bands (Fig. 4D) of discolored coral tissue. Lesions can develop on all areas of the coral colony, but are most common on upper surfaces (Santavy et al. 1999). A patch of exposed skeleton is often present at the center of each circular to irregularly shaped lesion and at the edge of each band- 

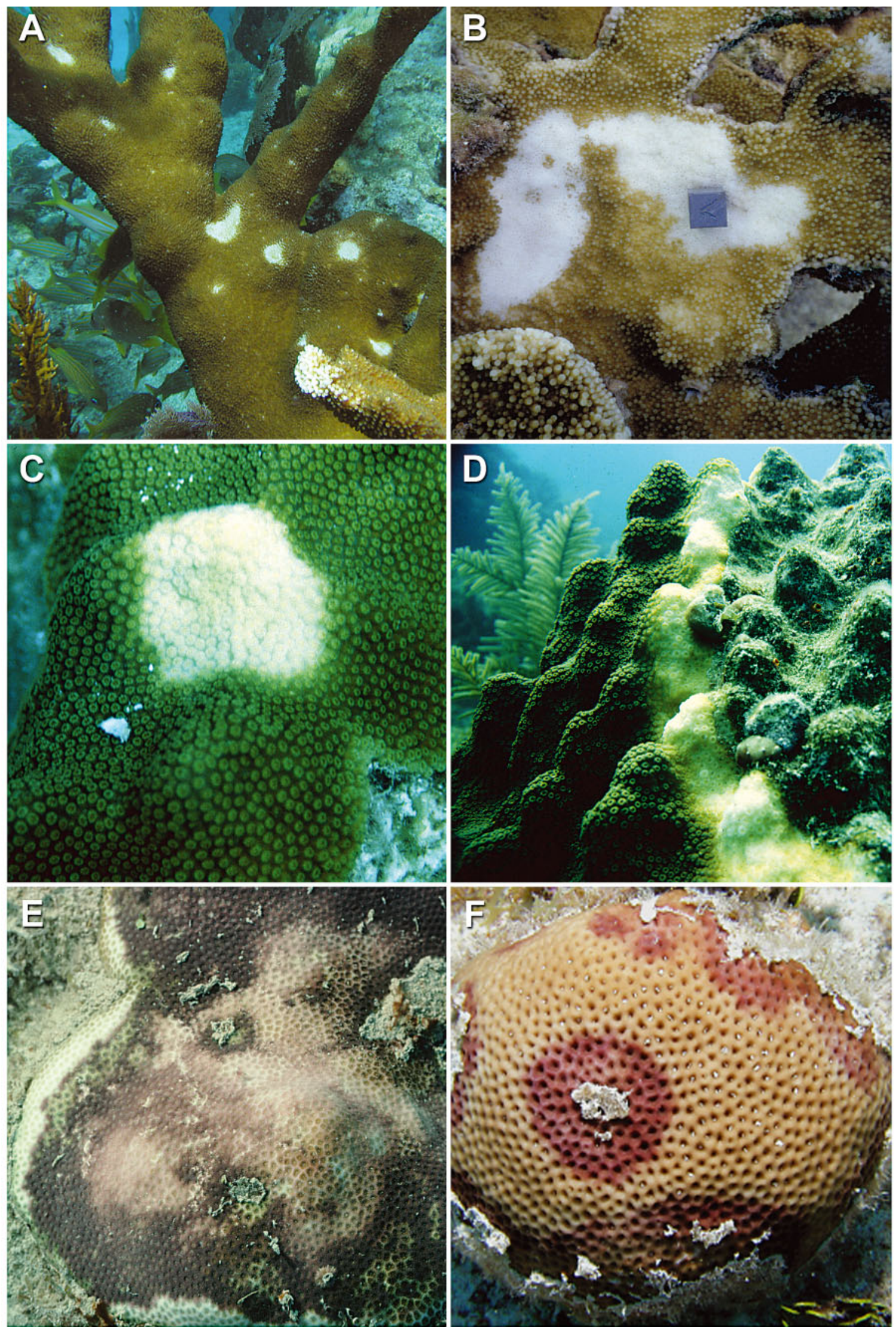
Fig. 4. Caribbean coral diseases: (A) white pox (WPD) on Acropora palmata; (B) WPD lesions on A. palmata; (C) yellow blotch/band (YBL) circular-shaped lesion and (D) YBL band-shaped lesion on Montastraea annularis complex; (E) dark spots (DSD) on Stephanocoenia michelinii; (F) DSD on Siderastrea siderea. Photographs: (A) and (E) by J.W.P., (B) by K.P.S., (C) and (D) by C. Quirolo, (F) by J.W.P. and C.T.

shaped lesion. This dead zone is surrounded by rings or bands of yellow translucent tissue, which may in turn be surrounded by rings or bands of pale brown to bright-white bleached tissue. Apparently healthy tissue surrounds the outer regions of YBL lesions (Santavy et al. 1999, Toller et al. 2001). Tissue loss rate associated with YBL is approximately $0.6 \mathrm{~cm} \mathrm{mo}^{-1}$ (Cervino et al. 2001).

YBL-affected coral tissues have approximately $40 \%$ fewer algal symbionts than do apparently healthy tissues, and these zooxanthellae appear vacuolated and lack organelles (Cervino et al. 2001). In San Blas (Panama) zooxanthellae within yellow and normal tissues from YBL-affected Montastraea annularis, $M$. faveolata, and $M$. franksi were found to be of different taxa of the genus Symbiodinium (Toller et al. 2001). Normal (unaffected) tissues were dominated by Symbiodinium sp., clade $\mathrm{C}$, the taxon common in healthy corals at depth of collection (1 to $10 \mathrm{~m}$ ). Yellow (affected) tissues predominately contained Symbiodinium sp., clade $\mathrm{A}$, the source of the characteristic yellow color of YBL lesions (Toller et al. 2001).

\section{Dark spots}

Dark spots disease (DSD; Fig. 4E,F) was first documented in the early 1990s in Colombia and today is found throughout the Caribbean (Goreau et al. 1998, Cervino et al. 2001, Garzón-Ferreira et al. 2001, Gil-Agudelo \& Garzón-Ferreira 2001, Weil et al. 2002). DSD reportedly affects 11 scleractinian species (Table 2; Goreau et al. 1998, Cervino et al. 2001, Garzón-Ferreira et al. 2001, Gil-Agudelo \& GarzónFerreira 2001).

DSD is characterized by irregularly shaped dark spots of purple, maroon, or brown coloration on normal tissue (Goreau et al. 1998). DSD may be associated with tissue necrosis and/or depression of the colony surface (Cervino et al. 2001). When DSD is associated with tissue loss, a spot may expand into a characteristic dark ring separating dead skeleton from living tissue (Goreau et al. 1998).

Dark pigmentation of DSD-affected Stephanocoenia michelinii extends into, and stains, the skeleton, and may be attributed to zooxanthellae, which appear darker in pigment in diseased corals of this species. In Siderastrea siderea affected with DSD, skeletal staining and zooxanthellae of darker pigmentation are not evident, but zooxanthellae do appear swollen and necrotic. These observations suggest that similar disease signs observed on S. michelinii (Fig. 4E) and S. siderea (Fig. 4F) may represent 2 different diseases (Cervino et al. 2001).

In the Colombian Caribbean, DSD is correlated with depth and temperature. DSD is more prevalent at depths less than $6 \mathrm{~m}$ and during summer when seawater temperature is highest (Table 5). Depth distribution of DSD may be due to high disease prevalence (94\%) on 2 coral species that occupy shallow depths, Siderastrea siderea and Montastraea annularis. Distribution of DSD on Colombian reefs is clumped, indicating that the disease may be contagious and therefore of biotic origin (Gil-Agudelo \& Garzón-Ferreira 2001). The causal agent of DSD is unknown.

\section{INDO-PACIFIC CORAL DISEASES}

\section{Vibrio-induced bleaching}

Coral bleaching is a global phenomenon that occurs when symbiotic algae (zooxanthellae) and/or their pigments are lost from host coral tissues, resulting in pale brown to translucent living tissue. This condition reduces reproductive output, skeletal growth, calcification rates, and nutrition (Porter et al. 1989, Brown 1997a), and therefore is a sign of disease. Bleaching is most often correlated with elevated seawater temperature, but may be associated with salinity extremes (Coles \& Jokiel 1992), light irradiance extremes (Brown et al. 1994, 2000, Brown 1997b, Shick et al. 1996), and pollutants (Peters et al. 1981, Harland \& Brown 1989). Bleaching may result in coral mortality, but most often the coral regains its algal symbionts, resulting in full recovery (Fitt et al. 1993).

Coral bleaching, once regarded exclusively as an abiotic condition, has recently been associated with 2 bacterial pathogens of the genus Vibrio. In the Mediterranean Sea, bleaching of the coral Oculina patagonica can be induced by an infection with the bacterium $V$. shiloi (Tables 3 \& 4; Kushmaro et al. 1996, 1997, 1998, 2001, Rosenberg et al. 1998). Bleaching and lysis of tissue of the coral Pocillopora damicornis in Zanzibar, Indian Ocean and Eilat, Red Sea are induced by infection with $V$. coralliilyticus (Tables 3 \& 4; Ben-Haim \& Rosenberg 2002, Ben-Haim et al. 2003a,b). Vibrioinduced bleaching and lysis are always associated with elevated seawater temperatures in excess of $24.5^{\circ} \mathrm{C}$ 
(Kushmaro et al. 1998, Toren et al. 1998, Ben-Haim et al. 1999, 2003b, Banin et al. 2001a, Israely et al. 2001), and therefore are examples of diseases with etiologies associated with both abiotic and biotic factors.

\section{Vibrio shiloi -induced bleaching}

Vibrio shiloi-induced bleaching (VSB) of Oculina patagonica is arguably the most characterized coral disease in terms of etiology and mechanism of pathogenesis. Koch's postulates were fullfilled and showed that bleaching can be induced by infection with $V$. shiloi in apparently healthy corals maintained at elevated seawater temperatures $\left(25\right.$ to $29^{\circ} \mathrm{C}$, Kushmaro et al. 1998). Elevated seawater temperatures increases the virulence of $V$. shiloi (Table 5; Kushmaro et al. 1998, Toren et al. 1998, Ben-Haim et al. 1999, Banin et al. 2001a, Israely et al. 2001).

Under conditions of elevated seawater temperatures, infection begins with adhesion of Vibrio shiloi to a $\beta$-galactoside-containing receptor in mucus on the surface of the host coral (Toren et al. 1998, Banin et al. $2001 b)$. Photosynthetically active zooxanthellae inside the host coral produce the $\beta$-galactoside-containing receptor. Only $V$. shiloi that are grown at elevated seawater temperatures are capable of adhesion (Toren et al. 1998). Therefore, adhesion only occurs under conditions of elevated temperature and if photosynthetically active zooxanthellae are present (Banin et al. 2001b).

The second step in the infection process is penetration of Vibrio shiloi into the epidermis of the host coral. Once $V$. shiloi are inside the tissues they multiply and transform into a viable but non-culturable state (VBNC). In other words, intracellular $V$. shiloi are not capable of forming colonies on media that support growth of extracellular V. shiloi. Intracellular bacteria are protected against effects of treatment with the antibiotic gentamicin. Gentamicin kills extracellular $V$. shiloi associated with coral mucus, but has no effect on $V$. shiloi that have successfully penetrated host tissue (Banin et al. 2000). At elevated temperatures, VBNC $V$. shiloi infect healthy coral and induce bleaching (Israely et al. 2001).

Following penetration into the host coral, Vibrio shiloi produces both heat-stable and heat-sensitive toxins that target zooxanthellae and play a role in pathogenesis. The heat-sensitive toxin bleaches and lyses symbiotic algal cells isolated from the host coral (Rosenberg et al. 1998, Ben-Haim et al. 1999). The extracellular heat-stable toxin, termed Toxin $\mathrm{P}$, is a proline-rich dodecapeptide that binds to zooxanthellae and inhibits photosynthesis in the presence of ammonia (Rosenberg et al. 1998, Ben-Haim et al. 1999, Banin et al. 2001a). Inhibition of photosynthesis damages zoo- xanthellae and contributes to coral bleaching (Banin et al. 2001a). Toxin P is produced only under conditions of elevated seawater temperature $\left(25\right.$ to $30^{\circ} \mathrm{C}$, Banin et al. 2001a). V. shiloi require another virulence factor, superoxide dismutase, in order to survive inside the host coral. High levels of superoxide dismutase are produced by $V$. shiloi under conditions of elevated seawater temperature $\left(30^{\circ} \mathrm{C}\right.$, Israely et al. 2001).

During summer in the Mediterranean Sea, Vibrio shiloi are present in all bleached colonies of Oculina patagonica. However, during winter, when water temperature drops to $16^{\circ} \mathrm{C}$, intracellular Vibrio shiloi lyse and die, and corals affected by VSB recover. $V$. shiloi outside the coral survive the temperature shift, indicating that the coral host may play a role in seasonal demise of the pathogen (Israely et al. 2001). Reinfection of $O$. patagonica colonies the following summer is facilitated, at least in part, by the marine fireworm Hermodice carunculata, which serves as a reservoir and a vector of $V$. shiloi. During winter, $V$. shiloi is present in the VBNC state inside $H$. carunculata, and during summer, when the worm feeds on O. patagonica, the VSB pathogen is transmitted to a few coral colonies. This indirect transmission serves to restart the infection process, and the infectious VSB then spreads from colony to colony (Sussman et al. 2003).

Vibrio coralliilyticus -induced bleaching and disease

Vibrio coralliilyticus-induced bleaching and disease (VCB) affects the scleractinian coral Pocillopora damicornis. VCB is characterized by bleaching (Ben-Haim et al. 2003b) and lysis of coral tissue (Ben-Haim \& Rosenberg 2002, Ben-Haim et al. 2003b). Koch's postulates were fulfilled and showed that VCB is caused by a new species of bacterium, V. coralliilyticus (Table 4; Ben-Haim \& Rosenberg 2002, Ben-Haim et al. 2003a,b). Bleaching and tissue loss associated with $V$. coralliilyticus is temperature dependent. Infection with $V$. coralliilyticus induces bleaching at seawater temperatures of 24.5 and $25.0^{\circ} \mathrm{C}$, and tissue lysis and colony death at seawater temperatures of 27 and $29^{\circ} \mathrm{C}$ (BenHaim et al. 2003b). Bleaching does not preceed lysis at temperatures greater than $27^{\circ} \mathrm{C}$ (Ben-Haim et al. 2003b). VCB is infectious and can be transmitted through direct contact between an infected coral colony and an un-infected neighbor (Ben-Haim \& Rosenberg 2002). V. coralliilyticus produces an extracellular protease that may play a role in pathogenesis, and production of this enzyme increases at temperatures greater than $24^{\circ} \mathrm{C}$ (Ben-Haim et al. 2003b). Elevated seawater temperature increases either pathogen virulence or host susceptibility, or both (Ben-Haim \& Rosenberg 2002). 


\section{Skeleton eroding band}

Skeleton eroding band (SEB) disease was first documented in 1988 in Papua New Guinea (Antonius \& Lipscomb 2000). SEB has since been observed in the Red Sea, Indian Ocean, and the Great Barrier Reef, Australia. Attempts to locate the disease in the Caribbean have been unsuccessful. Although Koch's postulates have not been fulfilled, SEB is believed to be caused by the protozoan Halofolliculina corallasia (Table 4). SEB affects 24 Indo-Pacific scleractinian species (Table 3; Antonius \& Lipscomb 2000).

Halofolliculina corallasia is a folliculinid heterotrich ciliate that is sessile in a secreted black sac-like test called a lorica. Dense clusters of protozoans, with basal portions of their loricae embedded in host coral skeleton, form the characteristic black band of SEB. SEB advances across a coral by asexually producing migratory larval stages that move ahead of the band in masses and locate a site to settle and secrete loricae. A combination of chemicals associated with production of pseudochitinous loricae, and drilling of loricae into coral skeleton, result in skeletal erosion and tissue death (Antonius \& Lipscomb 2000).

SEB resembles BBD in gross disease signs, except that SEB is not associated with a microbial mat that can be lifted from the coral surface. SEB affected corals are characterized by a black band ranging in width from less than $1 \mathrm{~mm}$ to $80 \mathrm{~cm}$, depending on species affected. The line migrates horizontally across affected coral at a rate that may be as slow as $1 \mathrm{~mm}$ $\mathrm{wk}^{-1}$ or as fast as $1 \mathrm{~mm} \mathrm{~d}^{-1}$, leaving dead skeleton in its wake. Denuded skeleton is flecked with tiny black spots composed of clusters of empty loricae, a characteristic that clearly distinguishes SEB from BBD, which leaves behind bright white skeleton (Antonius \& Lipscomb 2000).

SEB is found at depths ranging from 0 to $35 \mathrm{~m}$ and is most common at 0.5 to $3 \mathrm{~m}$. The disease does not appear to be correlated with seasonal seawater temperatures. SEB can be directly transmitted from a diseased colony to a healthy colony only via direct physical contact. Attempts to transmit the disease via seawater in enclosed aquaria were unsuccessful (Antonius \& Lipscomb 2000).

\section{Yellow band}

Yellow band disease (YBD) was first observed in the Gulf of Oman, Arabian Sea in the late 1990s. The disease affects 12 Indo-Pacific scleractinian coral species (Table 3; Korrûbel \& Riegl 1998, Riegl 2002). YBD is not the same disease as Caribbean yellow blotch/band disease (YBL).
YBD is characterized by a broad band of yellowpigmented tissue (Korrûbel \& Riegl 1998) and a yellowpigmented microbial mat (B. Riegl pers. comm.) that migrate horizontally across the coral, producing a margin of decaying tissue adjacent to healthy tissue and leaving behind dead skeleton that often retains a yellow pigmentation (Korrûbel \& Riegl 1998). The presence of a microbial mat suggests that YBD may be a variant of BBD (B. Riegl pers. comm.). Rate of tissue loss is correlated with seasonally elevated temperature and is greater in summer $\left(19.7 \mathrm{~mm} \mathrm{wk}^{-1}\right)$ than in winter (9.4 $\mathrm{mm} \mathrm{wk}^{-1}$, Table 5; Riegl 2002). YBD is transmissible from colony to colony (Riegl 2002).

\section{Pink-line syndrome}

Pink-line syndrome (PLS) was first reported in 2001 affecting the scleractinian corals Porites compressa and P. lutea of Kavaratti Island, Indian Ocean (Table 3). PLS is characterized by a band of pink-pigmented tissue separating dead skeleton from apparently healthy tissue. This band may begin as a small ring and progress outward horizontally across a coral colony. As with other coral diseases, the zone of dead skeleton is bright white in appearance, indicating a relatively rapid rate of disease progression (Ravindran et al. 2001). PLS is associated with the cyanobacterium Phormidium valderianum, which induces pink coloration of coral tissue, hypothesized by increasing levels of $\mathrm{pCO}_{2}$ (Ravindran \& Raghukumar 2002).

\section{Fungal-protozoan syndrome}

Epizootics affecting 6 gorgonian species, 1 scleractinian species (Table 3), 1 zoanthid (Parazoanthus axinellae), sponges, and encrusting coralline algae occurred in the Liguarian Sea, north-western Mediterranean, in late summer 1999. Losses of gorgonian corals were estimated to be in the millions (Cerrano et al. 2000).

Gorgonian corals affected by the syndrome, here termed fungal-protozoan syndrome (FPS), are characterized by an increase in mucus production, loss of pigmentation, and loss of coenenchyme tissue. Spicules in the coenenchyme lose the thin outer layer of epidermal cells and become disorganized. Coenenchyme tissues are colonized by fungi and coral polyps are colonized and consumed by protozoan ciliates. Fungi associated with FPS were most commonly of the genus Trichoderma, but Clodosporium, Penicillum, and Humicola were also common (Table 4; Cerrano et al. 2000).

Fungi and protozoa associated with FPS may be opportunistic rather than primary pathogens. FPS epizootics of 1999 were correlated with elevated seawater 
temperature (Table 5). The etiology of FPS may stem from a combination of an abiotic stressor (i.e. elevated seawater temperature) and a biotic attack by opportunistic microorganisms (Cerrano et al. 2000).

\section{CORAL IMMUNITY}

Immunity is the protection against infectious disease and can be innate or acquired (Stedman 2000). Knowledge of the immune systems of zooxanthellate corals and other invertebrates is limited; however, these organisms are known to possess highly efficient defense mechanisms against infection. In order to fully understand coral immunity, it is helpful to first briefly review the immune mechanisms of invertebrates in general.

Invertebrates are limited to innate immunity (Roch 1999), defined as a non-specific general ability of certain cells to resist most pathogens (Stedman 2000). Vertebrates, on the other hand, utilize both innate immunity and acquired immunity (Roch 1999, Stedman 2000), a specific and highly sophisticated mechanism for developing resistance to individual pathogens (Stedman 2000). Components of the acquired immune system, including antibodies, antigen presenting cells, interactive lymphocytes, and lymphoid organs are absent in invertebrates (Sinderman 1990).

Invertebrate and vertebrate immune responses are similar in that both types of organisms employ physiochemical barriers, cellular defenses, and humoral defenses against pathogens (Roch 1999). Physiochemical barriers serve as the first line of defense against invaders and include epidermis, mucus, cuticles, tests, shells, and gut barriers (Roitt et al. 1996, Peters 1997). Cellular (whole cell) defenses depend on the ability of the organism to distinguish non-self from self, and in invertebrates include: (1) coagulation and wound healing, (2) hemocytosis, (3) phagocytosis, (4) encapsulation, and (5) immunological memory (Kinne 1980, Sinderman 1990, Roitt et al. 1996). Invertebrates employ both natural and inducible humoral (cell product) defenses (Sinderman 1990, Roitt et al. 1996) that provide the lytic properties of phagocytic cells and hemolymph (blood, Sinderman 1990).

There is evidence for vertebrate defense mechanisms in invertebrates including cytokines, complement, and immunological memory (Roitt et al. 1996). Invertebrate cytokine-like molecules regulate invertebrate host defenses by activating phagocytosis and encapsulation. Invertebrates known to produce cytokine-like molecules include protozoa, annelids, echinoderms, tunicates, and arthropods (Roitt et al. 1996). Complement participates in control of inflammation, bacterial lysis, microbial killing, and phagocytosis (Roitt et al. 1996). Phagocytosis is enhanced when complement mole- cules, termed opsonins, bind to invading microorganisms or other foreign material (Bayne 1990, Roitt et al. 1996). Opsonin-dependent phagocytosis is found in a number of invertebrates including echinoderms, crustaceans, mollusks, annelids, and insects (Bayne 1990, Roitt et al. 1996). Immunological memory is a mechanism by which a host can distinguish non-self from self and resist infection by previously encountered pathogenic microorganisms (Sinderman 1990). Memory has been observed in scleractinian and gorgonian corals (Theodor 1970, Hildemann et al. 1975, 1977a, 1980a, Raison et al. 1976, Johnston et al. 1981, Bak \& Criens 1982, Neigel \& Avise 1983), sponges (Hildemann et al. 1979, 1980b, Hildemann \& Linthicum 1981, Bigger et al. 1982, 1983, Johnston \& Hildemann 1983), echinoderms (Karp \& Hildemann 1976, Hildemann et al. 1979), mollusks, crustaceans (Anderson 1986, Sinderman 1990), tunicates (Lakshma Reddy et al. 1975, Raftos et al. 1987), nemerteans (Langlet \& Bierne 1982), and annelids (Hildemann et al. 1979).

\section{Coral physiochemical barriers}

Scleractinian and gorgonian corals utilize mucus production and a protective epidermis as physiochemical barriers (Peters 1997, Santavy \& Peters 1997, Hayes \& Goreau 1998). Sloughing of mucus is an important defense mechanism of corals against attachment of potentially pathogenic bacteria to surface tissues (Ducklow \& Mitchell 1979a, Rublee et al. 1980). However, there are examples of mucus aiding in attachment of pathogenic microorganisms to the surface of corals. Adhesion of Vibrio shiloi, the pathogen that causes VSB, to the coral surface requires a $\beta$-galactoside-containing receptor in the mucus (Toren et al. 1998). Further, Lipp et al. (2002) demonstrated that potentially pathogenic enteric bacteria and viruses are concentrated on the surface mucus layers of scleractinian corals under natural near-shore conditions in the Florida Keys.

\section{Coral cellular defenses}

Cellular defenses depend on the ability of the coral to distinguish non-self (e.g. sediment, pathogens) from self. Cellular defenses documented for scleractinian and gorgonian corals include: (1) wound healing (Bigger \& Hildemann 1982, Meszaros \& Bigger 1999), (2) phagocytosis (Bayne 1990, Sinderman 1990, Peters 1997), and (3) immunological memory (Theodor 1970, Hildemann et al. 1975, 1977a, 1980a, Raison et al. 1976, Johnston et al. 1981, Bak \& Criens 1982, Neigel \& Avise 1983).

Wound healing involves the infiltration of granular amoebocytes to immobilize invading microorganisms 
(Bigger \& Hildemann 1982, Sinderman 1990). Coelenterate invertebrates, including scleractinian and gorgonian corals, have the ability to repair wounds, i.e. regenerate lost tissue (Patterson \& Landolt 1979, Meszaros \& Bigger 1999). Wound healing in coelenterates is carried out by mobile phagocytic cells, termed amoebocytes, that migrate from uninjured tissue, accumulate at the site of injury, and arrange into interconnected cell cords that form the healing front (Patterson \& Landolt 1979, Meszaros \& Bigger 1999). Amoebocytes also function to recognize, engulf, and destroy microbial invaders through phagocytosis (Bigger \& Hildemann 1982, Bayne 1990, Sinderman 1990, Meszaros \& Bigger 1999). For corals and other tropical marine invertebrates, phagocytosis is the principal cellular defense (Sinderman 1990, Peters 1997).

Immunological memory in corals is a component of allogenic recognition, the ability to distinguish self from non-self in tissue grafts. Corals accept isogenic (intracolony) grafts through complete fusion of tissue and skeleton (Hildemann et al. 1975, 1977a, Raison et al. 1976, Bak \& Criens 1982, Neigel \& Avise 1983, Jokiel \& Bigger 1994), but reject allogenic (intraspecies) and xenogenic (interspecies) grafts through cytotoxic interaction and necrosis (Theodor 1970, Hildemann et al. 1975, 1977a,b, 1980a,b, Raison et al. 1976, Johnston et al. 1981, Jokiel \& Bigger 1994). This aggression is accelerated for repeat grafts, indicating the presence of specific induced alloimmune memory (Theodor 1970, Raison et al. 1976, Hildemann et al. 1977a, 1980a,b, Johnston et al. 1981), an immune response generally reserved for vertebrates. However, in contrast to long-term vertebrate memory, coral alloimmune memory is short-term, lasting for a period of 2 to 4 wk (Raison et al. 1976, Hildemann et al. 1977a, 1980a,b). Cytotoxic reactions to both primary and secondary allografts are accelerated under conditions of seasonally elevated seawater temperatures $\left(27^{\circ} \mathrm{C}\right.$, Bigger \& Hildemann 1982, Johnston et al. 1981), suggesting that decreased temperatures $\left(21^{\circ} \mathrm{C}\right)$ may result in immunosuppression (Johnston et al. 1981), reducing a coral's ability to defend itself against pathogenic microorganisms.

Corals probably evolved mechanisms for cytotoxic attack due to the constant threat of overgrowth by adjacent benthic organisms. Scleractinian corals compete for space on the reef by utilizing a variety of defense mechanisms including: (1) rapid growth rate to overgrow neighbors (Lang 1973, Porter 1974, Maguire \& Porter 1977), (2) extrusion of mesenterial filaments to attack neighboring species, killing coral tissue via extracoelenteric digestion (Lang 1973, Porter 1974), and (3) allelochemical attack, resulting in tissue necrosis (Theodor 1970, Hildemann et al. 1975, Raison et al. 1976, Hildemann et al. 1977a,b, 1980a,b, Johnston et al. 1981).
Corals that grow rapidly (e.g. acroporids) and therefore can overgrow and outcompete neighbors for space, possess less potent mesenterial filaments and allelochemicals than do slower growing corals (Lang 1973, Porter 1974, Bak \& Criens 1982). Intracolony isografts of Acropora cervicornis (Neigel \& Avise 1983) and A. palmata (Bak \& Criens 1982) are characterized by complete fusion of tissue and skeleton. Intercolony allografts of these 2 species result in overgrowth of tissues of either graft over recipient colony or recipient colony over graft (Bak \& Criens 1982, Neigel \& Avise 1983), and fusion of the skeleton is evident in A. cervicornis allografts (Neigel \& Avise 1983). Xenografts of $A$. palmata and $A$. cervicornis are characterized by overgrowth where $A$. palmata consistently grows over A. cervicornis (Bak \& Criens 1982). Fusion of skeleton and overgrowth of tissues of allografts and xenografts indicate that acroporid corals utilize minimal antagonistic intraspecific and interspecific defenses (Bak \& Criens 1982, Neigel \& Avise 1983).

A number of cellular immune responses have been observed in scleractinian and gorgonian corals affected by coral disease. ASP-affected Caribbean gorgonian corals Gorgonia spp. utilize sclerite recruitment and nodule formation to sequester Aspergillus sydowii fungal hyphae and limit spread of infection (Smith et al. 1998). Similarly, Caribbean gorgonian corals Pseudoplexaura spp., with skeletal nodules caused by encapsulation of the algae Entocladia endozoica, produce many more sclerites than do healthy corals, and these sclerites surround and encapsulate the infected skeleton (Goldberg et al. 1984). Pseudoplexaura spp. with algal nodules produce large numbers of granular amoebocytes when algal filaments extend beyond the skeletal lesion and invade host mesoglea. These amoebocytes coat invading algae with a layer of mesoglealike material, and coated algae are then encapsulated by host skeleton (Goldberg et al. 1984). Indo-Pacific scleractinian corals Porites spp. detect invasion by endolithic fungi and respond by surrounding the site of fungal penetration within layers of repair calcium carbonate (Le Champion-Alsumard et al. 1995, Ravindran et al. 2001).

\section{Coral humoral defenses}

Corals employ both natural and inducible humoral defenses. Lysozyme and lysosomal enzymes are natural humoral defenses used by corals (Sinderman 1990). Lysozyme is an antimicrobial lysin found in phagocytic cells that destroys susceptible bacteria by elevating levels of lysosomal enzymes (Sinderman 1990). Lysosomal enzymes are contained within membrane-bound vesicles (lysosomes) and are granules 
containing bactericidal and hydrolytic substances that play a critical role in killing phagocytized microorganisms (Bayne 1990, Sinderman 1990). Antimicrobial activity is both natural and inducible in scleractinian and gorgonian corals. Corals utilize antibiotic compounds or noxious chemicals to repel potentially pathogenic or parasitic organisms (Kim 1994, Slattery et al. 1995, 1997, Jensen et al. 1996, Koh 1997, Peters 1997, Kelman et al. 1998, Kim et al. 2000a,b).

Jensen et al. (1996) and Kelman et al. (1998) tested antibiotic activity (i.e. inhibition of bacterial growth) of secondary metabolites from gorgonian corals against marine bacteria and concluded that gorgonians lack potent broad-spectrum chemical defenses. However, gorgonians do possess species-specific chemical defenses against potentially pathogenic microorganisms (Kim 1994, Kelman et al. 1998).

Kelman et al. (1998) examined extracts from various reproductive and developmental stages of the Red Sea gorgonian Pareythropodium fulvum fulvum against bacteria isolated from: (1) SML of $P$. fulvum fulvum, (2) apparently healthy and necrotic tissue of $P$. fulvum fulvum, (3) reef substrates adjacent to test corals, and (4) seawater in the vicinity of test corals. P. fulvum fulvum possessed species-specific chemical defenses against the potentially pathogenic bacterium Vibrio sp. isolated from necrotic tissue as well as against bacteria isolated from reef substrates and seawater, but lacked antimicrobial activity against commensal bacteria associated with SML and healthy coral tissue (Kelman et al. 1998).

Koh (1997) measured antimicrobial activity of extracts from 100 species (44 genera, 13 families) of scleractinian corals from the Great Barrier Reef against 6 marine bacteria isolated from Australian waters and one terrestrial bacterium. All 100 species exhibited antimicrobial activity against 1 marine cyanobacterium: Synechococcus sp. Significant activity against the other 5 marine bacteria and the terrestrial bacterium was detected in only 6 and 11 coral species, respectively, indicating that the majority of the corals did not employ chemical defenses against these potentially pathogenic bacterial species (Koh 1997).

Kim et al. (2000a) provide the first evidence of chemical defense mechanism against a known coral pathogen. Gorgonian corals possess inducible chemical defenses to resist infection with Aspergillus sydowii, the causal agent of ASP. Antifungal agents in crude extracts from Gorgonia ventalina and G. flabellum inhibit germination of A. sydowii spores (Kim et al. 2000a, Dube et al. 2002). Elevated summer seawater temperature $\left(30^{\circ} \mathrm{C}\right)$ reduces potency of Gorgonia crude extracts and promotes growth of A. sydowii (Alker et al. 2001).

Antifungal activity associated with ASP varies with health status and size class of host gorgonians and with lesion location on diseased individuals (Kim et al. 2000a, Dube et al. 2002, Kim \& Harvell 2002). Increased antifungal activity is inducible in ASP-affected gorgonians with lesions at the colony center (Kim et al. 2000a) and in diseased individuals that are larger and more mature (Dube et al. 2002). Prevalence and severity of ASP is greatest on the largest size class of affected sea fans (Dube et al. 2002, Kim \& Harvell 2002). Larger and/or older colonies may be more susceptible to Aspergillus sydowii as indicated by reduced potency of anti-fungal agents in their crude extracts (Kim \& Harvell 2002). Small colonies exhibit higher antifungal activity than do large colonies and are more resistant to ASP (Dube et al. 2002). Antifungal activity is greater in healthy than in diseased gorgonians, and this activity is concentrated at colony edges. Greater concentrations of antifungal agents in crude extracts from healthy gorgonians indicate that antifungal activity influences resistance to infection (Kim et al. 2000a).

\section{CONCLUSION}

Eighteen coral diseases, affecting at least 150 scleractinian, gorgonian, and hydrozoan zooxanthellate species, have been described from the Caribbean and the Indo-Pacific (Tables 1, 2 \& 3). Despite the greater species richness of the Indo-Pacific, the number of species affected by disease is proportionally much lower than in the Caribbean. Of the approximately 400 coral species in the Indo-Pacific, only $98(25 \%)$ have been documented with 1 or more diseases, while at least 52 of the 66 (82\%) Caribbean coral species are known to be susceptible to disease. Worldwide, 22 coral species are affected by 4 or more different diseases (Tables $2 \&$ 3 ), and 14 of these species belong to 4 genera (Acropora, Diploria, Colpophyllia, and Montastrea) that represent the most common, frame-building coral species. The susceptibility of these species to a wide array of diseases has the potential to change the composition, structure, and function of coral reef ecosystems.

In the Caribbean, WPL (40), BBD (25), SKA (22), DSD (11), and YBL (9) affect the greatest number of coral species (Table 2). Diseases affecting the greatest number of Indo-Pacific coral species include BBD (45), WPL-L (37), SKA (24), SEB (24), and YBD (12; Table 3). Caribbean and Indo-Pacific scleractinian corals are highly susceptible to plague-like diseases, including WPL I, WPL II, WPL III, WPL-L, WBD I, and WBD II (Tables $2 \& 3$ ). It is important to note that the gross disease signs used to identify plague-like diseases in the field (i.e. coral tissue loss and exposed white skeleton; Pantos et al. 2003) may simply be indicative of coral death. Further, in the Caribbean, gross signs of WBD differ from those of WPL only in species affected (i.e. branching species). Future research will indicate 
whether plague-like signs on Caribbean and IndoPacific coral species represent a single disease condition, caused by a single pathogen (e.g. Aurantimonas coralicida, Richardson et al. 1998a,b, Denner et al. 2003), or if similar disease signs documented for the plague-like diseases represent different diseases caused by a variety of pathogens.

Accumulating evidence suggests that human activity in the watershed may be causally related to coral decline. Increases in the number of both new diseases (Fig. 2) and species affected may be directly linked to human-induced alterations in coral reef environments both in terms of land-based sources of pollution as well as global climate change issues such as global warming (Table 5). Elevated seawater temperature may be associated with the etiologies of at least 9 coral conditions and is likely the most common abiotic stressor influencing disease pathogenicity (Table 5). Further, 5 coral disease-causing pathogens, including the BBD cyanobacteria, Aurantimonas coralicida (WPL II), Aspergillus sydowii (ASP), Vibrio shiloi (VSB), and V. coralliilyticus (VCB), are most virulent at seawater temperature at or above $29^{\circ} \mathrm{C}$ (Kushmaro et al. 1998, Alker et al. 2001, Banin et al. 2001a, Israely et al. 2001, Ben-Haim \& Rosenberg 2002, Kuta \& Richardson 2002, Ben-Haim et al. 2003b, Richardson \& Kuta 2003). Seawater temperature normally increases during late summer, but all current models of global climate change suggest that, on average, ocean temperatures will rise over the next century (Kleypas et al. 1999). Elevated temperature is a stressor in corals, causing thermally induced breakdown in the coral-zooxanthellae host-symbiont relationship (Porter et al. 1989, Fitt et al. 1993, Brown 1997b). Elevated temperature also promotes growth and virulence of pathogens (Kushmaro et al. 1996, 1998, Toren et al. 1998, Alker et al. 2001, Banin et al. 2001a, Israely et al. 2001, Ben-Haim \& Rosenberg 2002, Kuta \& Richardson 2002, Ben-Haim et al. 2003b, Richardson \& Kuta 2003) and reduces immune response in host corals (Toren et al. 1998, Alker et al. 2001).

Nutrient and sediment loading may deliver potentially pathogenic organisms to the marine environment. Transport of the terrestrial fungus Aspergillus sydowii, the causal agent of ASP, to the marine environment may be associated with local sediment run-off from land or long-distance atmospheric transport (Smith et al. 1996, Shinn et al. 2000). Increasing evidence suggests that the health of reef organisms is affected by sewage pollution. BBD and WPD may be associated with fecal contamination of possible human origin (Frias-Lopez et al. 2002, Patterson et al. 2002). Human enteric bacteria and viruses are prevalent on coral surfaces and in nearshore, offshore, and canal waters in the Florida Keys (Lapointe et al. 1990, Paul et al. 1995a,b, 1997, Griffin et al. 1999, Lipp et al. 2002). The
1983 epizootic affecting the Caribbean long-spined sea urchin Diadema antillarum caused catastrophic reductions in urchin populations (Lessios et al. 1984). It has been suggested that the fecal bacterium Clostridium perfringens may have been involved in the urchin dieoff (Bauer \& Agerter 1987, 1994). Since 1996, populations of the sewage consuming reef sponge Cliona delitrix have increased by a factor of 10 on reefs in the Florida Keys (Ward-Paige 2003) while, concurrently, corals have declined by $37 \%$ (Porter et al. 2002).

Etiologies of only 5 coral diseases have been determined through fulfillment of Koch's postulates, but several other disease conditions have been linked to specific biotic organisms (Table 4). The application of Koch's postulates for the identification of coral disease has severe drawbacks, and in order for the study of coral disease etiology to advance, alternative techniques for identifying disease-causing pathogens and abiotic stressors must be accepted and implemented. Knowledge of coral disease reservoirs, transmission, pathogenesis, and epizootiology is limited, and significant advances remain to be made in the field of coral immunology.

Acknowledgements. We thank C. Beaver, W. Jaap, P. Dustan, V. Kosmynin, and the crews of the RV 'Tortugas' and OSV 'Peter W. Anderson' for field assistance. We thank E. C. Peters and W. K. Fitt for comments on the manuscript, and C. Quirolo for field support and photographs. This research was supported by a US Environmental Protection Agency/University of West Florida Science Training in Ecology Program (STEP) Fellowship (to K.P.S.), by a US EPA grant EPA-FDEP X-9934649-94-0 (to J.W.P.), and by a Florida Department of Environmental Protection grant SP626 (E. K. Lipp, K.P.S. and J.W.P.).

\section{LITERATURE CITED}

Aeby GS (1998) A digenean metacercaria from the reef coral, Porites compressa, experimentally identified as Podocotyloides stenometra. J Parasitol 84:1259-1261

Alker AP, Smith GW, Kim K (2001) Characterization of Aspergillus sydowii (Thom et Church) a fungal pathogen of Caribbean sea fan corals. Hydrobiologia 460:105-111

Al-Moghrabi SM (2001) Unusual black band disease (BBD) outbreak in the northern tip of the Gulf of Aqaba (Jordan). Coral Reefs 19:330-331

Anderson RM (1986) Genetic variability in resistance to parasitic invasion: population implications for invertebrate host species. Symp Zool Soc Lond 56:239-274

Antonius A (1973) New observations on coral destruction in reefs. Abs Assoc Isl Mar Lab Caribb 10:3

Antonius A (1977) Coral mortality in reefs: a problem for science and management. Proc 3rd Int Coral Reef Symp Miami 2:617-623

Antonius A (1981) The 'band' diseases in coral reefs. Proc 4th Int Coral Reef Symp Philippines 2:7-14

Antonius A (1985a) Coral diseases in the Indo-Pacific: a first record. PSZN I: Mar Ecol 6:197-218

Antonius A (1985b) Black band disease infection experiments on hexacorals and octocorals. Proc 5th Int Coral Reef Congr Moorea 6:155-160 
Antonius A (1988) Distribution and dynamics of coral diseases in the Eastern Red Sea. Proc 6th Int Coral Reef Symp Townsville 2:293-298

Antonius AA, Lipscomb D (2000) First protozoan coral-killer identified in the Indo-Pacific. Atoll Res Bull 481:1-21

Antonius A, Riegl B (1997) A possible link between coral diseases and a corallivorous snail (Drupella cornus) outbreak in the Red Sea. Atoll Res Bull 447:1-9

Antonius A, Riegl B (1998) Coral diseases and Drupella cornus invasion in the Red Sea. Coral Reefs 17:48

Aronson RB, Precht WF (1997) Stasis biological disturbance and community structure of a Holocene coral reef. Paleobiology 23:326-346

Aronson RB, Precht WF (2001) White-band diseases and the changing face of Caribbean coral reefs. Hydrobiologia 460:25-38

Aronson RB, Precht WF, Macintyre IG (1998) Extrinsic control of species replacement on a Holocene reef in Belize: the role of coral disease. Coral Reefs 17:223-230

Aronson RB, Macintyre IG, Precht WF, Murdoch TJT, Wapnick CM (2002) The expanding scale of species turnover events on coral reefs in Belize. Ecol Monogr 72:233-249

Bak RPM (1983) Neoplasia regeneration and growth in the reef-building coral Acropora palmata. Mar Biol 77:221-227

Bak RPM, Criens SR (1982) Experimental fusion in Atlantic Acropora (scleractinia). Mar Biol Lett 3:67-72

Banin E, Israely T, Kushmaro A, Loya Y, Orr E, Rosenberg E (2000) Penetration of the coral-bleaching bacterium Vibrio shiloi into Oculina patagonica. Appl Environ Microbiol 66: 3031-3036

Banin E, Khare SK, Naider F, Rosenberg E (2001a) Prolinerich peptide from the coral pathogen Vibrio shiloi that inhibits photosynthesis of zooxanthellae. Appl Environ Microbiol 67:1536-1541

Banin E, Israely T, Fine M, Loya Y, Rosenberg E (2001b) Role of endosymbiotic zooxanthellae and coral mucus in the adhesion of the coral-bleaching pathogen Vibrio shiloi to its host. FEMS Microbiol Lett 199:33-37

Bauer JC, Agerter CJ (1987) Isolation of bacteria pathogenic for the sea urchin Diadema antillarum (Echinodermata: Echinoidea). Bull Mar Sci 40:161-165

Bauer JC, Agerter CJ (1994) Isolation of potentially pathogenic bacterial flora from tropical sea urchins in selected West Atlantic and East Pacific sites. Bull Mar Sci 55:142-150

Baya AM, Toranzo AE, Lupiani B, Santos Y, Hetrick FM (1992) Serratia marcescens: a potential pathogen for fish. J Fish Dis 15:15-26

Bayne CJ (1990) Phagocytosis and non-self recognition in invertebrates. BioScience 40:723-731

Ben-Haim Y, Rosenberg E (2002) A novel Vibrio sp pathogen of the coral Pocillopora damicornis. Mar Biol 141:47-55

Ben-Haim Y, Banin E, Kushmaro A, Loya Y, Rosenberg E (1999) Inhibition of photosynthesis and bleaching of zooxanthellae by the coral Vibrio shiloi. Environ Microbiol 1: 223-229

Ben-Haim Y, Thompson FL, Thompson CC, Cnockaert MC, Hoste B, Swings J, Rosenberg E (2003a) Vibrio coralliilyticus sp nov, a temperature-dependent pathogen of the coral Pocillopora damicornis. Int J Syst Evol Microbiol 53:309-315

Ben-Haim Y, Zicherman-Keren M, Rosenberg E (2003b) Temperature-regulated bleaching and lysis of the coral Pocillopora damicornis by the novel pathogen Vibrio coralliilyticus. Appl Environ Microbiol 69:4236-4242

Bigger CH, Hildemann WH (1982) Cellular defense systems of the Coelenterata. In: Cohen N, Sigel MM (eds) The reticuloendothelial system. Plenum Press, New York, p 59-87
Bigger CH, Jokiel PL, Hildemann WH, Johnston IS (1982) Characterization of alloimmune memory in a sponge. J Immunol 129:1570-1572

Bigger CH, Jokiel PL, Hildemann WH (1983) Cytotoxic transplantation immunity in the sponge Toxadocia violacea. Transplantation 35:239-243

Brown BE (1997a) Disturbances to reefs in recent times. In: Birkeland C (ed) Life and death of coral reefs. Chapman \& Hall, New York, p 354-379

Brown BE (1997b) Coral bleaching: causes and consequences. Coral Reefs 16:129-138

Brown BE, Dunne RP, Scoffin TP, Le Tissier MDA (1994) Solar damage in intertidal corals. Mar Ecol Prog Ser 105:219-230

Brown BE, Dunne RP, Goodson MS, Douglas AE (2000) Bleaching patterns in reef corals. Nature 404:142-143

Bruckner AW, Bruckner RJ (1997a) Outbreak of coral disease in Puerto Rico. Coral Reefs 16:260

Bruckner AW, Bruckner RJ (1997b) The persistence of black band disease in Jamaica: impact on community structure. Proc 8th Int Coral Reef Symp, Panama 1:601-606

Bruckner AW, Bruckner RJ (2002) Coral predation by Sparisima viride and lack of relationship with coral disease. Proc 9th Int Coral Reef Symp, Bali 2:1245-1249

Bruckner AW, Bruckner RJ, Williams EH Jr (1997) Spread of a black-band disease epizootic through the coral reef system in St Ann's Bay Jamaica. Bull Mar Sci 61:919-928

Bythell J, Sheppard C (1993) Mass mortality of Caribbean shallow corals. Mar Pollut Bull 26:296-297

Bythell JC, Barer MR, Cooney RP, Guest JR, O'Donnell AG, Pantos O, Le Tissier MDA (2002) Histopathological methods for the investigation of microbial communities associated with disease lesions in reef corals. Lett Appl Microbiol 34:359-364

Carlton RG, Richardson LL (1995) Oxygen and sulfide dynamics in a horizontally migrating cyanobacterial mat: black band disease of corals. FEMS Microbiol Ecol 18: 155-162

Cerrano C, Bavestrello G, Bianchi CN, Cattaneo-vietti R and 8 others (2000) A catastrophic mass-mortality episode of gorgonians and other organisms in the Ligurian Sea (Northwestern Mediterranean) summer 1999. Ecol Lett 3:284-293

Cervino J, Goreau TJ, Goreau M, Smith G and 11 others (1997) Rapid spread of diseases in Caribbean coral reefs. Proc Assoc Isl Mar Lab Caribb 28:43

Cervino J, Goreau TJ, Nagelkerken I, Smith GW, Hayes R (2001) Yellow band and dark spot syndromes in Caribbean corals: distribution rate of spread cytology and effects on abundance and division rate of zooxanthellae. Hydrobiologia 460:53-63

Cheney DP (1975) Hard tissue tumors of scleractinian corals. In: Hildemann WH, Benedict AA (ed) Immunologic phylogeny. Plenum, New York, p 77-87

Cheng TC, Wong AKL (1974) Chemical, histochemical, and histopathological studies on corals, Porites spp., parasitized by trematode metacercariae. J Invertebr Pathol 23:303-317

Coles SL (1994) Extensive coral disease outbreak at Fahl Island Gulf of Oman Indian Ocean. Coral Reefs 13:242

Coles SL, Jokiel PL (1992) Effects of salinity on coral reefs. In: Connell DW, Hawker DW (ed) Pollution in tropical aquatic systems. CRC Press, Boca Raton, FL, p 147-166

Coles SL, Seapy DG (1998) Ultra-violet absorbing compounds and tumorous growths on acroporid corals from Bandar Khayran Gulf of Oman Indian Ocean. Coral Reefs 17: 195-198

Cooney RP, Pantos O, Le Tissier MDA, Barer MR, O'Donnell AG, Bythell JC (2002) Characterization of the bacterial consortium associated with black band disease in coral 
using molecular microbiological techniques. Environ Microbiol 47:401-413

Denner EBM, Smith G, Busse HJ, Schumann P, Narzt T, Polson SW, Lubitz W, Richardson LL (2003) Aurantimonas coralicida gen. nov., sp. nov., the causative agent of white plague type II on Caribbean scleractinian corals. Int J Syst Evol Microbiol 53:1115-1122

Diaz-Soltero H (1999) Endangered and threatened species: a revision of candidate species list under the Endangered Species Act. Fed Register 64(210):33 466-33 468

Dinsdale EA (2002) Abundance of black-band disease on corals from one location on the Great Barrier Reef: a comparison with abundance in the Caribbean region. Proc 9th Int Coral Reef Symp, Bali 2:1239-1243

Dube D, Kim K, Alker AP, Harvell CD (2002) Size structure and geographic variation in chemical resistance of sea fan corals Gorgonia ventalina to a fungal pathogen. Mar Ecol Prog Ser 231:139-150

Ducklow H, Mitchell R (1979a) Bacterial populations and adaptations in the mucus layers on living corals. Limnol Oceanogr 24:715-725

Ducklow H, Mitchell R (1979b) Observations on naturally and artificially diseased tropical corals: a scanning electron microscope study. Microbiol Ecol 5:215-223

Dustan P (1977) Vitality of reef coral populations off Key Largo Florida: recruitment and mortality. Environ Geol 2:51-58

Dustan P (1999) Coral reefs under stress: sources of mortality in the Florida Keys. Nat Res Forum 23:147-155

Edmunds PJ (1991) Extent and effect of black band disease on a Caribbean reef. Coral Reefs 10:161-165

Evans AS (1976) Causation and disease: the Henle-Koch postulates revisited. Yale J Biol Med 49:175-195

Falkow S (1988) Molecular Koch's postulates applied to microbial pathogenicity. Rev Infect Dis 10:S274-S276

Feingold JS (1988) Biological studies of a cyanobacterial infection on the Caribbean sea plume Pseudopterogorgia acerosa (Coelenterata: Octocorallia). Proc 6th Int Coral Reef Symp, Townsville 3:157-162

Fitt WK, Spero H, Halas J, White M, Porter J (1993) Recovery of the coral Montastraea annularis in the Florida Keys after the 1987 Caribbean 'bleaching event.' Coral Reefs 12:57-64

Fredricks DN, Relman DA (1996) Sequence-based identification of microbial pathogens: a reconsideration of Koch's postulates. Clin Microbiol Rev 9:18-33

Frias-Lopez J, Zerkle AL, Bonheyo GT, Fouke BW (2002) Partitioning of bacterial communities between seawater and healthy black band diseased and dead coral surfaces. Appl Environ Microbiol 68:2214-2228

Frias-Lopez J, Bonheyo GT, Jin Q, Fouke BW (2003) Cyanobacteria associated with coral black band disease in Caribbean and Indo-Pacific reefs. Appl Environ Microbiol 69:2409-2413

Garrett P, Ducklow H (1975) Coral diseases in Bermuda. Nature 253:349-350

Garzón-Ferreira JM, Zea S (1992) A mass mortality of Gorgonia ventalina (Cnidaria: Gorgoniidae) in the Santa Marta area Caribbean coast of Colombia. Bull Mar Sci 50:522-526

Garzón-Ferreira J, Gil-Agudelo DL, Barrios LM, Zea S (2001) Stony coral diseases observed in southwestern Caribbean reefs. Hydrobiologia 460:65-69

Geiser DM, Taylor JW, Ritchie KB, Smith GW (1998) Cause of sea fan death in the West Indies. Nature 394:137-138

Gil-Agudelo DL, Garzón-Ferreira J (2001) Spatial and seasonal variation of dark spots disease in coral communities of the Santa Marta area (Colombian Caribbean). Bull Mar Sci 69:619-629

Gladfelter EH, Monahan RK, Gladfelter WB (1978) Growth rates of five reef-building corals in the northeastern Caribbean. Bull Mar Sci 28:728-734

Gladfelter WB (1982) White-band disease in Acropora palmata: implications for the structure and growth of shallow reefs. Bull Mar Sci 32:639-643

Glynn PW, Howard LS, Corcoran E, Cofer-Shabica SV (1984) The occurrence and toxicity of herbicides in reef building corals. Mar Pollut Bull 15:370-374

Goldberg WM, Makemson JC, Colley SB (1984) Entocladia endozoica sp nov a pathogenic chlorophyte: structure life history physiology and effect on its coral host. Biol Bull 166:368-383

Goreau TJ, Cervino J, Goreau M, Hayes R and 14 others (1998) Rapid spread of diseases in Caribbean coral reefs. Rev Biol Trop 46:157-171

Green EP, Bruckner AW (2000) The significance of coral disease epizootiology for coral reef conservation. Biol Conserv 96:347-361

Greenstein BJ, Curran HA, Pandolfi JM (1998) Shifting ecological baselines and the demise of Acropora cervicornis in the western North Atlantic and Caribbean Province: a Pleistocene perspective. Coral Reefs 17:249-261

Griffin DW, Gibson III CJ, Lipp EK, Riley K, Paul III JH, Rose JB (1999) Detection of viral pathogens by reverse transcriptase PCR and of microbial indicators by standard methods in the canals of the Florida Keys. Appl Environ Microbiol 65:4118-4125

Grimont PA, Grimont F (1994) Genus VIII Serratia Bizio, 1823. In: Holt JG, Kreig NR, Sneath PHA, Staley JT, Williams ST (eds) Bergey's manual of determinative bacteriology, Vol 4. Williams \& Wilkins, Baltimore, p 477-484

Grygier MJ, Cairns SD (1996) Suspected neoplasms in deepsea corals (Scleractinia: Oculinidae: Madrepora spp.) reinterpreted as galls caused by Petrarca madreporae n. sp. (Crustacea: Ascothoracida: Petrarcidae). Dis Aquat Org 24:61-69

Harland AD, Brown BE (1989) Metal tolerance in the scleractinian coral Porites lutea. Mar Pollut Bull 20:353-357

Harvell CD, Kim K, Burkholder JM, Colwell RR and 9 others (1999) Emerging marine diseases-climate links and anthropogenic factors. Science 285:1505-1510

Harvell D, Kim K, Quirolo C, Weir J, Smith G (2001) Coral bleaching and disease: contributors to 1998 mass mortality in Briareum asbestinum (Octocorallia Gorgonacea). Hydrobiologia 460:97-104

Hayes RL, Goreau TJ (1998) The significance of emerging diseases in the tropical coral reef ecosystem. Rev Biol Trop 46:173-185

Hildemann WH, Linthicum DS (1981) Transplantation immunity in the Palaun sponge Xestospongia exigua. Transplantation 32:77-80

Hildemann WH, Linthicum DS, Vann DC (1975) Transplantation and immunoincompatibility reactions among reefbuilding corals. Immunogenetics 2:269-284

Hildemann WH, Raison RL, Cheung G, Hull CJ, Akaka L, Okamoto J (1977a) Immunological specificity and memory in a scleractinian coral. Nature 270:219-223

Hildemann WH, Raison RL, Hull CJ, Akaka LK, Okamoto J, Cheung GP (1977b) Tissue transplantation immunity in corals. Proc 3rd Int Coral Reef Symp Miami 1:538-543

Hildemann WH, Johnson IS, Jokiel PL (1979) Immunocompetence in the lowest Metazoan phylum: transplantation immunity in sponges. Science 204:420-422

Hildemann WH, Jokiel PL, Bigger CH, Johnston IS (1980a) Allogeneic polymorphism and alloimmune memory in the coral Montipora verrucosa. Transplantation 30:297-301 Hildemann WH, Bigger CH, Johnston IS, Jokiel PL (1980b) 
Characteristics of transplantation immunity in the sponge Callyspongia diffusa. Transplantation 30:362-367

Hill AB (1965) The environment and disease: association or causation? Proc R Soc Med 58:295-300

Hodgson G (1990) Tetracycline reduces sedimentation damage to corals. Mar Biol 104:493-496

Holden C (1996) Coral disease hot spot in the Florida Keys. Science 274:2017

Huebner RJ (1957) The virologist's dilemma. Ann NY Acad Sci 67:430-438

Hughes TP (1994) Catastrophes phase shifts and large-scale degradation of a Caribbean coral reef. Science 265:1547-1551

Hunter CL, Peters EC (1993) Effects of stress-induced necrosis and 'tumors' on the scleractinian coral Porites lobata in Hawaii. Am Zool 33:19A

Israely T, Banin E, Rosenberg E (2001) Growth differentiation and death of Vibrio shiloi in coral tissue as a function of seawater temperature. Aquat Microb Ecol 24:1-8

Jensen PR, Harvell CD, Wirtz K, Fenical W (1996) Antimicrobial activity of extracts of Caribbean gorgonian corals. Mar Biol 125:411-419

Johnson RT, Gibbs CJ (1974) Koch's postulates and slow infections of the nervous system. Arch Neurol 30:36-38

Johnston IS, Hildemann WH (1983) Morphological correlates of intraspecific grafting reactions in the marine demosponge Callyspongia diffusa. Mar Biol 74:25-33

Johnston IS, Jokiel PL, Bigger CH, Hildemann WH (1981) The influence of temperature on the kinetics of allograft reactions in a tropical sponge and a reef coral. Biol Bull 160:280-291

Jokiel PL, Bigger CH (1994) Aspects of histocompatibility and regeneration in the solitary reef coral Fungia scutaria. Biol Bull 186:72-80

Jolles AE, Sullivan P, Alker AP, Harvell CD (2002) Disease transmission of aspergillosis in sea fans: inferring process from spatial pattern. Ecology 83:2373-2378

Karp RD, Hildemann WH (1976) Specific allograft reactivity in the sea star Dermasterias imbricata. Transplantation 22: 434-439

Kelman D, Kushmaro A, Loya Y, Kashman Y, Benayahu Y (1998) Antimicrobial activity of a Red Sea soft coral Parerythropodium fulvum fulvum: reproductive and developmental considerations. Mar Ecol Prog Ser 169:87-95

Kendrick B, Risk MJ, Michaelides J, Bergman K (1982) Amphibious microborers: bioeroding fungi isolated from live corals. Bull Mar Sci 32:862-867

Kim K (1994) Antimicrobial activity in gorgonian corals (Coelenterata Octocorallia). Coral Reefs 13:75-80

Kim K, Harvell CD (2002) Aspergillosis of sea fan corals: disease dynamics in the Florida Keys. In: Porter JW, Porter KG (ed) The Everglades Florida Bay and coral reefs of the Florida Keys: an ecosystem sourcebook. CRC Press, New York, p 813-824

Kim K, Harvell CD, Smith GW (1997) Mechanisms of sea fan resistance to a fungal epidemic. I. Role of sclerites. Am Zool 37:132A

Kim K, Harvell CD, Kim PD, Smith GW, Merkel SM (2000a) Fungal disease resistance of Caribbean sea fan corals (Gorgonia spp). Mar Biol 36:259-267

Kim K, Kim PD, Alker AP, Harvell CD (2000b) Chemical resistance of gorgonian corals against fungal infections. Mar Biol 137:393-401

Kinne O (1980) Diseases of marine animals: general aspects. In: Kinne O (ed) Diseases of marine animals, Vol 1. General aspects, Protozoa to Gastropoda. John Wiley \& Sons, New York

Kleypas JA, Buddemeier RW, Archer D, Gattuso JP, Langdon C, Opdyke BN (1999) Geochemical consequences of increased atmospheric carbon dioxide on coral reefs. Science 284:118-120

Koch R (1882) Die Aetiologie der Tuberculose. Berl Klinische Wochenschrift 19:221-230

Koh EGL (1997) Do scleractinian corals engage in chemical warfare against microbes? J Chem Ecol 23:379-398

Korrûbel JL, Riegl B (1998) A new coral disease from the Arabian Gulf. Coral Reefs 17:22

Kushmaro A, Loya Y, Fine M, Rosenberg E (1996) Bacterial infection and coral bleaching. Nature 380:396

Kushmaro A, Rosenberg E, Fine M, Loya Y (1997) Bleaching of the coral Oculina patagonica by Vibrio AK-1. Mar Ecol Prog Ser 147:159-165

Kushmaro A, Rosenberg E, Fine M, Ben-Haim Y, Loya Y (1998) Effect of temperature on bleaching of the coral Oculina patagonica by Vibrio shiloi AK-1. Mar Ecol Prog Ser 171:131-137

Kushmaro A, Banin E, Loya Y, Stackebrandt E, Rosenberg E (2001) Vibrio shiloi sp nov the causative agent of bleaching of the coral Oculina patagonica. Int J Syst Evol Microbiol 51:1383-1388

Kuta KG, Richardson LL (1996) Abundance and distribution of black band disease on coral reefs in the northern Florida Keys. Coral Reefs 15:219-223

Kuta KG, Richardson LL (2002) Ecological aspects of black band disease of corals: relationships between disease incidence and environmental factors. Coral Reefs 21:393-398

Lakshma Reddy A, Bryan B, Hildemann WH (1975) Integumentary allograft versus autograft reactions in Ciona intestinalis: a protochordate species of solitary tunicate. Immunogenetics 1:584-590

Lang J (1973) Interspecific aggression by scleractinian corals. 2. Why the race is not only to the swift. Bull Mar Sci 23:260-279

Langlet C, Bierne J (1982) Immune characteristics of graft rejection in nemerteans of the genus Lineus. Eur J Immunol 12:705-708

Lapointe BE, O'Connell JD, Garrett GS (1990) Nutrient coupling between on-site sewage disposal systems groundwaters and nearshore surface waters of the Florida Keys. Biogeochemistry 10:289-307

Le Champion-Alsumard T, Golubic S, Priess K (1995) Fungi in corals: symbiosis or disease? Interaction between polyps and fungi causes pearl-like skeleton biomineralization. Mar Ecol Prog Ser 117:137-147

Lessios HA, Robertson DR, Cubit JD (1984) Spread of Diadema mass mortality through the Caribbean. Science 226:335-337

Lipp EK, Jarrell JL, Griffin DW, Lukasik J, Jacukiewicz J, Rose JB (2002) Preliminary evidence for human fecal contamination in corals of the Florida Keys, USA. Mar Poll Bull 44:666-670

Littler MM, Littler DS (1996) Black band disease in the South Pacific. Coral Reefs 15:20

Loya Y, Bull G, Pichon M (1984) Tumor formations in scleractinian corals. Helgol Wiss Meeresunters 37:99-112

Maguire LA, Porter JW (1977) A spatial model of growth and competition strategies in coral communities. Ecol Model 3: $249-271$

Meszaros A, Bigger C (1999) Qualitative and quantitative study of wound healing processes in the coelenterate Plexaurella fusifera: spatial temporal and environmental (light attenuation) influences. J Invertebr Pathol 73:321-331

Miller I (1996) Black band disease on the Great Barrier Reef. Coral Reefs 15:58

Miller MW, Bourgue AS, Bohnsack JA (2002) An analysis of the loss of acroporid corals at Looe Key, Florida USA: 1983-2000. Coral Reefs 21:179-182

Mitchell R, Chet I (1975) Bacterial attack of corals in polluted water. Microb Ecol 2:227-233 
Morse DE, Morse ANC, Duncan H (1977) Algal 'tumors' in the Caribbean sea-fan Gorgonia ventalina. Proc 3rd Int Coral Reef Symp Miami 1:623-629

Morse DE, Morse A, Duncan H, Trench RK (1981) Algal tumors in the Caribbean octocorallian Gorgonia ventalina: II. Biochemical characterization of the algae and first epidemiological observations. Bull Mar Sci 31:399-409

Muntanola-Cvetkovic M, Ristanovic B (1980) A mycological survey of the south Adriatic Sea. J Exp Mar Biol Ecol 43: 193-206

Nagelkerken I, Buchan K, Smith GW, Bonair K and 10 others (1997a) Widespread disease in Caribbean sea fans: II. Patterns of infection and tissue loss. Mar Ecol Prog Ser 160: $255-263$

Nagelkerken I, Buchan K, Smith GW, Bonair K and 8 others (1997b) Widespread disease in Caribbean sea fans: I. Spreading and general characteristics. Proc 8th Int Coral Reef Symp, Panama 1:679-682

Neigel JE, Avise JC (1983) Clonal diversity and population structure in a reef-building coral, Acropora cervicornis: self-recognition analysis and demographic interpretation. Evolution 37:437-453

Nugues MM (2002) Impact of a coral disease outbreak on coral communities in St Lucia: what and how much has been lost? Mar Ecol Prog Ser 229:61-71

Pantos O, Cooney RP, Le Tissier MDA, Barer MR, O'Donnell AG, Bythell JC (2003) The bacterial ecology of a plaguelike disease affecting the Caribbean coral Montastrea annularis. Environ Microbiol 5:370-382

Patterson KL, Porter JW, Ritchie KB, Polson SW, Mueller E, Peters EC, Santavy DL, Smith GW (2002) The etiology of white pox a lethal disease of the Caribbean elkhorn coral Acropora palmata. Proc Natl Acad Sci USA 99:8725-8730

Patterson MJ, Landolt ML (1979) Cellular reaction to injury in the Anthozoan Anthopleura elegantissima. J Invertebr Pathol 33:189-196

Paul JH, Rose JB, Brown J, Shinn EA, Miller S, Farrah SR (1995a) Viral tracer studies indicate contamination of marine waters by sewage disposal practices in Key Largo, Florida. Appl Environ Microbiol 61:2230-2234

Paul JH, Rose JB, Jiang S, Kellogg C, Shinn EA (1995b) Occurrence of fecal indicator bacteria in surface waters and the subsurface aquifer in Key Largo, Florida. Appl Environ Microbiol 61:2235-2241

Paul JH, Rose JB, Jiang SC, Zhou X and 6 others (1997) Evidence for groundwater and surface marine water contamination by waste disposal wells in the Florida Keys. Water Res 31:1448-1454

Peters EC (1984) A survey of cellular reactions to environmental stress and disease in Caribbean scleractinian corals. Helgol Meeresunters 37:113-137

Peters EC (1993) Diseases of other invertebrate phyla: Porifera, Cnidaria, Ctenophora, Annelida, Echinodermata. In: Couch JA, Fournie JW (eds) Pathobiology of marine and estuarine organisms. CRC Press, Boca Raton, FL, p 393-449

Peters EC (1997) Diseases of coral reef organisms. In: Birkeland C (ed) Life and death of coral reefs. Chapman \& Hall, New York, p 114-139

Peters EC, Meyers PA, Yevich PP, Blake NJ (1981) Bioaccumulation and histopathological effects of oil on a stony coral. Mar Pollut Bull 12:333-339

Peters EC, Yevich PP, Oprandy JJ (1983) Possible causal agent of 'white band disease' in Caribbean acroporid corals. J Invertebr Pathol 41:394-396

Peters EC, Halas JC, McCarty HB (1986) Calicoblastic neoplasms in Acropora palmata with a review of reports on anomalies of growth and form in corals. J Natl Cancer Inst
76:895-912

Porter JW (1974) Community structure of coral reefs on opposite sides of the Isthmus of Panama. Science 186:543-545

Porter JW, Tougas JI (2001) Reef ecosystems: threats to their biodiversity. Encyclopedia of biodiversity, Vol 5. Academic Press, San Diego, p 73-95

Porter JW, Fitt WK, Spero HJ, Rogers CS, White MW (1989) Bleaching in reef corals: physiological and stable isotopic responses. Proc Natl Acad Sci USA 86:9342-9346

Porter JW, Dustan P, Jaap WC, Patterson KL, Kosmynin V, Meier OW, Patterson ME, Parsons M (2001) Patterns of spread of coral disease in the Florida Keys. Hydrobiologia 460:1-24

Porter JW, Kosmynin V, Patterson KL, Porter KG and 13 others (2002) Detection of coral reef change by the Florida Keys Coral Reef Monitoring Project. In: Porter JW, Porter KG (eds) The Everglades Florida Bay and coral reefs of the Florida Keys. CRC Press, Boca Raton, FL, p 749-769

Raftos DA, Tait NN, Briscoe DA (1987) Allograft rejection and alloimmune memory in the solitary urochordate Styela plicata. Dev Comp Immunol 11:343-351

Raison RL, Hull CJ, Hildemann WH (1976) Allogenic graft rejection in Montipora verrucosa, a reef-building coral. In: Wright RK, Cooper EL (eds) Phylogeny of thymus and bone marrow-bursa cells. Elsevier/North-Holland Biomedical Press, Amsterdam, p 3-8

Ramos-Flores T (1983) Lower marine fungus associated with black line disease in star corals (Montastraea annularis E \& S). Biol Bull 165:429-435

Ravindran JC, Raghukumar C (2002) Pink line syndrome (PLS) in the scleractinian coral Porites lutea. Coral Reefs 21:252

Ravindran J, Raghukumar C, Raghukumar S (2001) Fungi in Porites lutea: association with healthy and diseased corals. Dis Aquat Org 47:219-228

Richardson LL (1993) Red band disease: a new cyanobacterial infestation of corals. Pure Appl Chem 1:153-160

Richardson LL (1996) Horizontal and vertical migration patterns of Phormidium corallyticum and Beggiatoa spp. associated with black-band disease of corals. Microb Ecol 32:323-335

Richardson LL (1997) Occurrence of the black band disease cyanobacterium on healthy corals of the Florida Keys. Bull Mar Sci 61:485-490

Richardson LL (1998) Coral diseases: what is really known? Trends Ecol Evol 13:438-443

Richardson LL, Kuta KG (2003) Ecological physiology of the black band disease cyanobacterium Phormidium corallyticum. FEMS Microbiol Ecol 43:287-298

Richardson LL, Kuta KG, Schnell S, Carlton RG (1997) Ecology of the black band disease microbial consortium. Proc 8th Int Coral Reef Symp Balboa 1:597-600

Richardson LL, Goldberg WM, Carlton RG, Halas JC (1998a) Coral disease outbreak in the Florida Keys: plague type II. Rev Biol Trop 46:187-198

Richardson LL, Goldberg WM, Kuta KG, Aronson RB and 5 others (1998b) Florida's mystery coral killer identified. Nature 392:557-558

Richardson LL, Smith GW, Ritchie KB, Carlton RG (2001) Integrating microbiological microsensor molecular and physiologic techniques in the study of coral disease pathogenesis. Hydrobiologia 460:71-89

Richmond RH (1993) Coral reefs: present problems and future concerns resulting from anthropogenic disturbance. Am Zool 33:524-536

Riegl B (2002) Effects of the 1996 and 1998 positive sea-surface temperature anomolies on corals, coral diseases and fish in the Arabian Gulf (Dubai, UAE). Mar Biol 140:29-40

Ritchie KB, Smith GW (1995a) Carbon-source utilization patterns of coral associated marine heterotrophs. J Mar 
Biotechnol 3:105-107

Ritchie KB, Smith GW (1995b) Preferential carbon utilization bysurface bacterial communities from water mass normal and white-band diseased Acropora cervicornis. Mol Mar Biol Biotechnol 4:345-352

Ritchie KB, Smith GW (1998) Type II white-band disease. Rev Biol Trop 46:199-203

Ritchie KB, Polson SW, Smith GW (2001) Microbial disease causation in marine invertebrates: problems, practices, and future prospects. Hydrobiologia 460:131-139

Rivers TM (1937) Viruses and Koch's postulates. J Bacteriol 33:1-12

Roch P (1999) Defense mechanisms and disease prevention in farmed marine invertebrates. Aquaculture 172:125-145

Rodríquez-Martínez RE, Banaszak AT, Jordán-Dahlgren E (2001) Necrotic patches affect Acropora palmata (Scleractinia: Acroporidae) in the Mexican Caribbean. Dis Aquat Org 47:229-234

Roitt I, Brostoff J, Male D (1996) Immunology, 4th edn. Mosby, New York

Rosenberg E, Ben-Haim Y, Toren A, Banin E, Kushmaro A, Fine M, Loya Y (1998) Effect of temperature on bacterial bleaching of corals. In: Rosenberg E (ed) Current perspectives in microbial ecology. ASM Press, Washington, DC, p 242-254

Rublee PA, Lasker HR, Gottfried M, Roman MR (1980) Production and bacterial colonization of mucus from the soft coral Briarium asbestinum. Bull Mar Sci 30:888-893

Rützler K, Santavy D (1983) The black band disease of Atlantic reef corals. I. Description of a cyanophyte pathogen. PSZN I: Mar Ecol 4:301-319

Rützler K, Santavy DL, Antonius A (1983) The black band disease of Atlantic reef corals. III. Distribution ecology and development. PSZN I: Mar Ecol 4:329-358

Santavy DL, Peters EC (1997) Microbial pests: coral disease research in the western Atlantic. Proc 8th Int Coral Reef Symp Balboa 1:607-612

Santavy DL, Peters EC, Quirolo C, Porter JW, Bianchi CN (1999) Yellow-blotch disease outbreak on reefs of the San Blas Islands Panama. Coral Reefs 18:97

Santavy DL, Mueller E, Peters EC, MacLaughlin L, Porter JW, Patterson KL, Campbell J (2001) Quantitative assessment of coral diseases in the Florida Keys: strategy and methodology. Hydrobiologia 460:39-52

Schnell S, Assmus B, Richardson LL (1996) Role of sulfate-reducing bacteria in the black band disease of corals. Annual Meeting of the VAAM (Vereinigung fuer Allgemeine und Angewandte Mikrobiologie) and GBCH (Gesellschaft fuer Biologische Chemie). Biospektrum, p 116

Shick JM, Lesser MP, Jokiel PL (1996) Effects of ultraviolet radiation on corals and other coral reef organisms. Glob Chang Biol 2:527-545

Shinn EA, Smith GW, Prospero JM, Betzer P, Hayes ML, Garrison V, Barber RT (2000) African dust and the demise of Caribbean coral reefs. Geophys Res Lett 27:3029-3032

Sinderman CJ (1990) Principal diseases of marine fish and shellfish, Vol 2, 2nd edn. Academic Press, New York

Slattery M (1999) Fungal pathogenesis of the sea fan Gorgonia ventalina: direct and indirect consequences. Chemoecology 9:97-104

Slattery M, McClintock JB, Heine JN (1995) Chemical defenses in Antarctic soft corals: evidence for antifouling compounds. J Exp Mar Biol Ecol 190:61-77

Slattery M, Hamann MT, McClintock JB, Perry TL, Puglisi MP, Yoshida WY (1997) Ecological roles for water-borne metabolites from Antarctic soft corals. Mar Ecol Prog Ser 161:133-144
Smith GW, Ives LD, Nagelkerken IA, Ritchie KB (1996) Caribbean sea-fan mortalities. Nature 383:487

Smith GW, Harvell CD, Kim K (1998) Response of sea fans to infection with Aspergillus sp. (Fungi). Rev Biol Trop 46: 205-208

Squires DF (1965) Neoplasia in a coral? Science 148:503-505

Stedman TL (2000) Stedman's medical dictionary, 27th edn. Lippincott Williams \& Wilkins, Baltimore

Sussman M, Loya Y, Fine M, Rosenberg E (2003) The marine fireworm Hermodice carunculata is a winter reservoir and spring-summer vector for the coral-bleaching pathogen Vibrio shiloi. Environ Microbiol 5:250-255

Sutherland KP, Ritchie KB (in press) White pox disease of the Caribbean elkhorn coral Acropora palmata. In: Rosenberg E, Loya Y (eds) Coral health and disease. Springer-Verlag, Heidelberg

Taylor DL (1983) The black band disease of Atlantic reef corals. PSZN I: Mar Ecol 4:321-328

Theodor JL (1970) Distinction between 'self' and 'not-self' in lower invertebrates. Nature 227:690-692

Toller WW, Rowan R, Knowlton N (2001) Repopulation of zooxanthellae in the Caribbean corals Montastraea annularis and $M$. faveolata following experimental and disease-associated bleaching. Biol Bull 201:360-373

Toren A, Landau L, Kushmaro A, Loya Y, Rosenberg E (1998) Effect of temperature on adhesion of Vibrio strain AK-1 to Oculina patagonica and on coral bleaching. Appl Environ Microbiol 64:1379-1384

US BOC (US Bureau of the Census) (2000) 2000 Census of Population. US Department of Commerce, Economics and Statistics Division, US BOC, Washington, DC

US EPA (US Environmental Protection Agency) (2000) Stressor identification document. Office of Water, Office of Research and Development, US EPA, Washington, DC

Veron J (1985) Aspects of the biogeography of hermatypic corals. Proc 5th Int Coral Reef Cong Tahiti 4:83-88

Veron J (1995) Corals in space and time. The biogeography and evolution of the Scleractinia. Comstock-Cornell Press, Ithaca, NY

Viehman TS, Richardson LL (2002) Motility patterns of Beggiatoa and Phormidium corallyticum in black band disease. Proc 9th Int Coral Reef Symp, Bali 2:1251-1255

Ward-Paige CA (2003) Bioerosion surveys on the Florida reef tract suggest widespread land-based stress on reefs. MS thesis, McMaster Univ, Ontario

Weil E, Urreiztieta I, Garzón-Ferreira J (2002) Geographic variability in the incidence of coral and octocoral diseases in the wider Caribbean. Proc 9th Int Coral Reef Symp Bali 2:1231-1237

Weir JW, Garrison V, Shinn EA, Smith GW (in press) The relationship between gorgonian coral (Cnidaria: Gorgonacea) diseases and African dust storms. Aerobiology

Wells J (1973) New and old scleractinian corals from Jamaica. Bull Mar Sci 23:16-58

Werner T, Allen G (ed) (1998) A rapid biodiversity assessment of the coral reefs of Milne Bay Province, Papua New Guinea. Conservation International, Washington, DC

Wheaton J, Jaap WC, Porter JW, Kosmynin V and 7 others (2001) EPA/FKNMS Coral Reef Monitoring Project Executive Summary. FKNMS Symposium: an ecosystem report card. Florida Mar Res Inst, St. Petersburg, FL

Wilkinson C (ed) (2002) Status of coral reefs of the world: 2002. Australian Institute of Marine Science, Townsville

Yamashiro H, Yamamoto M, van Woesik R (2000) Tumor formation on the coral Montipora informis. Dis Aquat Org 41:211-217

Submitted: June 17, 2002; Accepted: November 6, 2003

Proofs received from author(s): January 9, 2004
Editorial responsibility: Charles Birkeland (Contributing Editor), Honolulu, Hawaii, USA 